
centrasiatiques et tibétaines

$50 \mid 2019$

Animals in the religion and culture of the Tibetan

Plateau

\title{
The use of insects in Tibetan medicine
}

L'utilisation des insectes dans la médecine tibétaine

Olaf Czaja

\section{(2) OpenEdition}

Journals

Electronic version

URL: https://journals.openedition.org/emscat/3994

DOI: $10.4000 /$ emscat.3994

ISSN: 2101-0013

Publisher

Centre d'Etudes Mongoles \& Sibériennes / École Pratique des Hautes Études

\section{Electronic reference}

Olaf Czaja, "The use of insects in Tibetan medicine", Études mongoles et sibériennes, centrasiatiques et tibétaines [Online], 50 | 2019, Online since 04 March 2019, connection on 13 July 2021. URL: http://

journals.openedition.org/emscat/3994 ; DOI: https://doi.org/10.4000/emscat.3994

This text was automatically generated on 13 July 2021.

(c) Tous droits réservés 


\title{
The use of insects in Tibetan medicine
}

\author{
L'utilisation des insectes dans la médecine tibétaine
}

\author{
Olaf Czaja
}

\section{AUTHOR'S NOTE}

In this article the phonetic transcription developed by the Tibetan and Himalayan Library (THL) is used in order to make Tibetan terms accessible to non-specialists. On the THL transcription system, see Germano \& Tournadre 2003.

\section{Introduction}

1 The use of animals for medicinal purposes, in parts or in the form of animal-derived products, is a feature of most medical systems in Asia and throughout the world ${ }^{1}$. The historical record shows that the use of animal-based remedies is an extremely old practice, which can be found in the pharmacological texts of not only the Egyptian medical tradition, but also those of the Mesopotamian, Roman, and Greek medical traditions ${ }^{2}$. The phenomenon of zootherapy - that is, using therapeutics based on medicines obtained from animals, or ultimately deriving from them - occurs all over the world, and reaches back into antiquity ${ }^{3}$. Domestic and wild animals, as well as their by-products, were important ingredients in drugs used for curative, protective, and preventive medicine. In both the past and the present, the use of animal-based medicines has had far-reaching implications in terms of ecology and ecomony ${ }^{4}$. Their availability and accessibility have long been a concern for doctors using animals and their by-products, and the potential of overexploitation is a real threat, which has been alleviated by the mass rearing of animals, including medicinal insects 5 . According to Lokeshwari and Shantibala, one can broadly classify the current exploitation and utilization of insects into four different categories ${ }^{6}$. First, insects are used as industrial 
resources, such as lac and natural dye. Second, they are consumed as food and taken as medicine. Third, they appear in forensic entomology, and finally they possess a high ecological importance regarding biomass recycling and so on. The medicinal use of insects, i.e. entomotherapy, has drawn the attention and the resources of pharmacological researchers in the search for new drugs ${ }^{7}$. Many such researchers hope to find bioactive compounds that may lead to new therapeutics. Shrivastava and Prakash, for example, see the potential for the discovery of new drugs, especially with regard to cytotoxins and anticancer compounds, neurotoxins, antibiotics, and antivirals ${ }^{8}$. A famous example is cantharidin and its derivatives, which can be found in several species of blister beetles of the genera Mylabris and Lytta (Meloidae) ${ }^{9}$. Mylabris cichorii is, for instance, found in parts of India and China, and it seems that it was also used in Tibetan medicine (see below).

2 The Chinese and Indian medical traditions, both of which have had a lasting influence on the Tibetan medical tradition, are known to draw on animals for curing diseases, including a wide range of insects. It has been said that about $13 \%$ of the medicinal substances used in Chinese medicine derive from animals ${ }^{10}$. Some authors speak of more than 1500 animal species that have been recorded to be of some medicinal use in the Chinese tradition ${ }^{11}$. According to Feng et al., in Chinese medicine there are approximately 300 medicinal insect species distributed across 70 genera, 63 families, and 14 orders, and an estimated 1700 traditional Chinese medicine prescriptions include medicinal insects or insect-derived crude drugs ${ }^{12}$. They point out that in the earliest Chinese pharmacopeia, more than twenty kinds of insect-derived drugs from eight species of insects are recorded. The famous Compendium of Materia Medica (Bencao gangmu) composed by Li Shizhen (1518-1593) contains seventy-three types of insectbased drugs, which derive from sixty species of insects. It is estimated that more than one hundred kinds of medicinal insects have been recorded for use in ancient times ${ }^{13}$.

It has also been estimated that in Ayurveda about $15-20 \%$ of its materia medica derive from animal products. In the Caraka-samphitā, for example, 230 types of animals and 380 types of animal substances are mentioned. Similarly, approximately 225 types of animals are mentioned in the Suśruta-saṃhitā. Most of these references discuss animals as food and medicine $\mathrm{e}^{14}$. Beside the classical texts of Ayurveda, medicinal animals are an integral part of folk medicine. A recent review summarizing and analysing the data in fifteen research works on zootherapeutic practices in different parts of India concludes that about 109 animals are used in 270 medical applications ${ }^{15}$. With regard to insects specifically, studies have shown that they are used in various ways among Indian ethnic communities. Some edible insects are consumed, and others are gathered for therapeutic uses ${ }^{16}$. Building upon this background, the present article seeks to clarify the therapeutic importance of medicinal insects and introduce some of the insects that were used in the Tibetan medical tradition by analysing traditional medical sources.

\section{The classification of animals in the Tibetan medical tradition}

4 The earliest preserved sources of the Tibetan medical tradition are the medical texts found at Dunhuang and Turfan. They can be tentatively dated to around the $9^{\text {th }}$ or $10^{\text {th }}$ century. They are available in the form of modern editions and on online databases ${ }^{17}$. They give important insights into the application of plant, mineral, animal, 
and human substances in the early instructional texts of Tibetan medicine. Previous research has shown that some of these substances originate in far-off regions and were made accessible to the Tibetan doctors via long-distance trade, which is reflected in the specific Tibetan names for certain remedies and materia medica that clearly show signs of their foreign origins, such as the remedy theriac, and the medicinal substances camphor and saffron ${ }^{18}$. Tibetan areas also contributed to this pan-Asian trade network, by supplying substances like musk, for example ${ }^{19}$. Even in these early sources, animal products are mentioned as components of drugs, but these were not the only uses of animal substances. Felt, for example, was also used to treat wounds, and milk was recommended to accompany the ingestion of certain drugs. The size of the droppings of certain animals also served as a standard of comparison when creating medicinal pills ${ }^{20}$.

5 Although animal substances were an integral part of Tibetan medicine, there are only a few systematic and detailed descriptions of them. Even in early sources, details regarding the appearance of the animal and where it is found are very rarely provided, which is in contrast to plants that are often described in detail. The first systematic list of animal materia medica in the Tibetan medical tradition was prepared by Yutok Yönten Gönpo (g.Yu thog Yon tan mgon po, fl. $12^{\text {th }}$ century) in the $20^{\text {th }}$ chapter of the Explanatory Tantra of his fundamental work, the Four Tantras ${ }^{21}$. There he distinguishes different types of materia medica based on the substance from which they are composed, such as precious stones and so on. The last category of this schema is animal-based medicine, and it is the category in which formulae for most, but not all, animal products have been compiled. Some animal products can also be found in the category called "medicinal sap" (tsimen, rtsi sman), which can derive from roots, trees, and animals. The most important "animal sap" or "animal secretion" are (elephant's) bezoar, musk, and bear bile.

6 The category of medicinal animals in the Four Tantras is further classified into thirteen sub-categories. These include (1) horns, (2) bones, (3) flesh, (4) blood, (5) bile, (6) fat, (7) brain, (8) skin, (9) nails, claws, beaks, and hooves, (10) small hairs and feathers, (11) urine, (12) faeces, and (13) the bodies of insects. Reviewing each item in the list, however, it becomes clear that other categories - such as the liver, stomach, lungs, tongues, and testicles of the animals - were also used to classify animal products used in medicines. These lists also include substances of human origin such as human bones, flesh, fat, brain, urine and faeces. Taken as a whole, the category of medicinal animals comprises ninety-six kinds of animal substances. Based on the respective categories, there are nine kinds of horns, fifteen kinds of bones (including cowry and snail shell), thirteen kinds of flesh, three types of liver, one kind of stomach, four kinds of tongues, two kinds of testicles, eight kinds of blood, four kinds of fat, five kinds of brain, four kinds of skin, one kind of beak or scale, three kinds of hooves, four kinds of feathers, two kinds of thin hair, two kinds of urine, ten kinds of faeces, and seven kinds of whole bodies of insects and others. Note that bile is listed in the overview but not further exemplified in the list, because it is, as already mentioned above, dealt with in the category of "medicinal sap". In this regard, Yönten Gönpo mentions the bile of a bear only but as it will discussed below the bile of various animals could be used for medicinal purposes as indicated by Tendzin Püntsok. However, it would be mistaken that to think that these lists represent all animal substances mentioned in the Four Tantras. In the Instructional Tantra, for example, one finds further substances not 
included in the list found in the Explanatory Tantra. Sangyé Gyamtso (Sangs rgyas rgya mtsho, 1653-1705), who wrote a commentary entitled the Blue Beryl on the Four Tantras, adds the substances described in the Instructional Tantra in his discussion about materia medica, and also includes them among the illustrations in his series of medical thangkas $^{22}$. For several centuries, the commentarial literature on the Four Tantras remained the main written source for systematic information on animals used in Tibetan medicine.

7 Scholarship on matera medica within the Tibetan medical tradition completely changed with the seminal work known as the Lumps of Crystal. A Rosary of Crystal (Shel gong shel phreng) written by Tendzin Püntsok (bsTan 'dzin phun tshogs, b. 1672). His work covers all sorts of materia medica, and consists of two separate works: Lumps of Crystal, which is a concise list of materia medica and their healing potentials, and A Rosary of Crystal, which is its commentary. The ninth section of this work describes medicinal substances that derive from animals, and it is subdivided into twenty-nine divisions, occasionally with subitems. The divisions include (1) horns and so on, (2) eyes, (3) tongues, (4) teeth, (5) throats and necks, (6) hearts, (7) lungs, (8) livers, (9) bile, (10) spleens, (11) kidneys, (12) stomachs, (13) small intestines, (14) genitals, (15) bones and so on, (16) bone marrow, (17) brain, (18) fat, (19) blood, (20) flesh, (21) skin, hide, and so on, (22) hair and so on, (23) feathers, (24) nails, claws, beaks, and hooves, (25) bezoar, (26) faeces, (27) urine and semen, (28) milk including milk, curd, and butter, and (29) whole bodies of insects, eggs of birds, and so on. Similarly to the Four Tantras, "animal secretions", such as musk and bear bile, are included in the section on "medicinal sap". In general, Tendzin Püntsok used the Four Tantras as the main base for his treatise, but expanded, supplemented, and elaborated upon it. The total number of body parts deriving from different species varies, for example, and is not the same as the Four Tantras. He lists the eyes used for medicinal purposes as coming from five species, and he describes the tongues of seven animals that can be of help in curing diseases. Concerning the brain, he registers sixteen types of brains from different animals, and also from humans. The biggest demand was apparently for the bile of nineteen animals, including humans, as well as fifty-three types of bones coming from animals such as sheep, goats, fish, snail shells, tortoises, fossils, and humans. According to Tendzin Püntsok, many animals possessed several parts that could potentially be of use in Tibetan medicine. A doctor might use the neck, stomach, brain, meat, feathers, and excrement of the bearded vulture, known as gowo (go bo) in Tibetan ${ }^{23}$. Similarly, the cinereous vulture called jagö (bya rgod) had several body parts that were of interest, such as the eyes, neck, heart, bile, stomach, bones, and flesh, as well as its excrement and urine ${ }^{24}$. In contrast to his long descriptions of plants, however, Tendzin Püntsok does not discuss the animals in any significant degree of detail. He usually just names them and neglects any further information regarding where they can be found, how they live, and so on.

8 Scholarship on animal-based materia medica further progressed in the $19^{\text {th }}$ century when a monk from Inner Mongolia composed a treatise on materia medica in the Tibetan language. In his Beautifully Wondrous Eye Ornament (mDzes mtshar mig rgyan), Jampel Dorjé ('Jam dpal rdo rje), alias Yeshé Döndrup Tenpé Gyemtsen (Ye shes don grub bstan pa'i rgyal mtshan, 1792-1855), includes illustrations that mostly derive from the Bencao gangmu, originally written by Li Shizhen and later printed in numerous editions ${ }^{25}$. In addition to Tibetan names for materia medica, he also includes Manchu, Mongolian, and Chinese names, and the latter with a rough pronunciation in Tibetan. It was never of great significance for the Tibetan medical tradition, but it become important for 
Mongolian medicine. Partially deviating from the precedents set by the Four Tantras, Jampel Dorjé chose some new criteria for the classification of materia medica, which becomes most obvious with regard to animals. He divides the animal-based materia medica into eight categories, which consist of:

1. Animals scratching with their feet

2. Animals pecking with their beaks

3. Herbivorous animals

4. Carnivorous animals

5. Animals eating with force

6. Animals domesticated by humans

7. Animals living in dens and burrows

8. Animals living in water and damp places ${ }^{26}$.

9 These classifications are quite unsual and are not found in other Tibetan works on materia medica. Jampel Dorjé certainly took the sixteenth chapter of the Explanatory Tantra which deals with the normal diet, including meat and fish, as a basis for his categories, but Yutok Yönten Gönpo distinguishes between several kinds of animal flesh, illustrating them by giving examples ${ }^{27}$. It should be noted that Yutok Yönten Gönpo enumerates a total of nine categories, but they are collectively referred to as only eight categories (sde brgyad ${ }^{28}$ ). It is possible that the third and fourth categories were once considered to be a single category, or a category was later inserted into the Four Tantras ${ }^{29}$. Commentators on the Four Tantras, such as Kyempa Tsewang (sKyem pa Tshe dbang, b. 1514) and Sangyé Gyamtso did not see this difference between eight and nine categories as important. The commentary of Pema Karpo (Padma dkar po, 1527-1592), which only identifies the main and sub-points of Four Tantras, counts only eight categories, lacking the category of large animals in the open mountains ${ }^{30}$. The same applies to the commentary written by Lozang Chödrak (Blo bzang chos grags, $\left.1638-1710^{31}\right)$.

10 The schema for the categorization of animals in the Four Tantras derives from the Ayurvedic treatise, the Aștāngahṛdaya-saṃhitā of Vāgbhața. In the latter book, accessible to Tibetan scholars through translation, the normal diet is discussed in the sixth chapter of the first book, which describes a normal diet ${ }^{32}$. Regarding flesh and meat, Vāgbhața classifies the animals in eight classes, based on zoological categories known in ancient India ${ }^{33}$.

11 In the Beautifully Wondrous Eye Ornament, Jampel Dorjé provides a brief description of each animal and sometimes their healing potential, with the latter information deriving from either the Four Tantras, the Blue Beryl, or A Rosary of Crystal. In a few cases, his descriptions might also include mythical animals, such as the so-called Kalanta bird. He places the Kalanta bird in the first group of animals, labelled as the "category of animals digging with their claws", which can be traced back to the Ayurvedic category, viskira (trönko, khron rko). One can interpret the Sanskrit term literally as birds that "scatter their food with their feet", or as birds that "scratch the soil in search of food $^{34 "}$ ". Tibetan translators of the Sanskrit term have interpreted viskira to mean birds that "dig/scratch (the soil) with their claws (in search of food)". Jampel Dorjé chose to group the Kalanta bird under this category, most of which are known species. Therein he describes it as follows (Fig. 5):

Kalantaka: The baby bird (indicates) that an auspicious time has begun. The body (of the adult bird) is large and its tail feathers, which are of five colours, are very beautiful. His singing entangles those who have ears, and when he hovers (in the sky), all the big and small birds follow him. In the Lumps of Crystal it is stated: "The 
head of the male pigeon Kalantaka is a powerful drug for the restoration of virility, and it is the best among the remedies for healing wounds". The baby bird, which is pleasent to hear, resembles a pigeon and is greenish. One must not confuse it with the Kalapingga (bird $\left.{ }^{35}\right)$.

The illustration, as well as the names listed in Mongolian, Manchurian, and Chinese make it clear that Jampel Dorjé is describing a phoenix. This is surprising because the phoenix does not generally play a role in Tibetan mythology or in Tibetan medicine. The reference to the Lumps of Crystal is also misleading, for Tendzin Püntsok is describing a real bird and not the mythological phoenix. The Kalantaka bird sometimes occurs in Buddhist literature, but it remains unclear what kind of birds it is ${ }^{36}$. Thus, Jampel Dorjé is combining several different descriptions of birds, both real and mythological, by introducing the Kalanta bird into the Tibetan medical tradition. At the same time, he warns that one should not confuse the Kalanta bird with another mythological being, the kalapingga (in Tibetan) or kalavinka (in Sanskrit), which is a mythological half-human creature with the body of a bird and a long flowing tail. It is famous for its sweet voice ${ }^{37}$.

\section{The medicinal insects in Tibetan medicine}

13 It should be noted at the outset that insects were used only to a very limited extent in Tibetan medicine. The only important exception is the lac insect (gyakyek, rgya skyegs), which can be found in numerous Tibetan drugs. The honey of bees has often been added to drugs (drangtsi, sbrang rtsi) as well ${ }^{38}$. In the following paragraphs, eleven insects that are mentioned in Tibetan medical treatises will be discussed, demonstrating how Tibetan doctors described them, potential identifications provided by modern authors, and which healing potentials they are said to possess ${ }^{39}$. The medicinal insects considered include flies, ants, two insects whose existence is doubtful, cicadas, butterflies, grasshoppers, and four kinds of beetles ${ }^{40}$. Their Tibetan names and their Western identifications are listed in the appendix, along with further references.

\section{Shadrang (sha sbrang)}

The term shadrang - literally rendered as "flesh bee" or "flesh fly" - occurs in neither the Four Tantras nor its commentaries. It does occur in the treatise Ten Million Instructions: Relics (Bye ba ring bsrel) written by Nyamnyi Dorjé (mNyam nyid rdo rje, 1439-1475), however. There it is said that one should use the body of the "flesh fly" with big eyes as an ingredient in a remedy for "restoring virility" (rotsa, ro tsa $\left.{ }^{41}\right)$. In the $18^{\text {th }}$ century, Nyamnyi Dorjé's drug was included in three important lists of Tibetan medicaments, one compiled by Tendzin Püntsok, and two by Karma Ngedön Tendzin Trinlé Rapgyé (Karma nges don bstan 'dzin 'phrin las rab rgyas, b. 1770 ${ }^{42}$ ). Orgyen Tekchok (O rgyan Theg mchog, b. $19^{\text {th }}$ century) also adds it to his drug section on "restoring virility ${ }^{43}$ ". In the prestigious compilation of Tibetan drugs prepared by the Mentsikhang in Lhasa in 2005, this medicament is listed as the drug named Soma Senggé-25 (sro ma seng ge nyer lnga ${ }^{44}$ ). The "flesh fly" is not discussed by any other scholars, with the exception of the contemporary Chinese scholar Luo Dashang, who states that it might be used to boost the male sex drive ${ }^{45}$. 


\section{Raksha mikmé (raksha mig med)}

If one consults modern publications on Tibetan materia medica written by Tibetan authors, one will come across statements on the use of ants in Tibetan medicine. They uniformily identify such ants as Formica fusca, a black-coloured ant, but it remains unclear how they came to this precise identification ${ }^{46}$. With the exception of the treatise written by Jampel Dorjé, there are only a few sketchy traditional descriptions of ants in Tibetan medical literature. Jampel Dorjé states that their bodies are segmented into heads, upper, and lower bodies, and that they are black, have six legs, and emerge from nests. Because ant nests in India are big like fortresses, they are depicted as emerging from just such a nest in the Beautifully Wondrous Eye Ornament (Fig. ${ }^{47}$ ). In the Tibetan language, ants are also called raksha mikmé, which literally means "eyeless demons" (raksha mig med). In A Rosary of Crystal by Tendzin Püntsok, it is said that ants can open "channels" and purify muchu $\left(\mathrm{dmu} c \mathrm{ch} \mathrm{u}^{48}\right)$, which is characterised by accumulation of fluids in the body ${ }^{49}$. Tendzin Püntsok probably drew this information from the Blue Beryl of Sangyé Gyamtso, where this statement is also made ${ }^{50}$. In this regard, Sangyé Gyamtso also mentions the use of soil from an anthill for supressing the "swelling of the flesh" (shatrang, sha skrangs ${ }^{51}$ ). Although he provides no details for how this is done, one can assume that he was influenced by the Ayurvedic tradition, in which such a use is recommended and explained. In the twenty-first chapter of the Aștāngahrdaya-saṃhitā, for example, in the section on therapeutics for "wind" (vāta) diseases, Vāgbhața discusses a medicinal paste that includes the soil of an anthill together with mustard and honey ${ }^{52}$. The use of ants themselves is not mentioned in Vāgbhata's work, however. This particular use of soil of an anthill is also depicted in the famous Tibetan medical paintings that serve as illustrations for the Blue Beryl (Fig. 153).

Moreover, it seems that in the past some doctors thought that ants could be used for the diagnosis of poisoning. In the eighty-seventh chapter of the Instructional Tantra dealing with "compounded poison" (jarduk, sbyar dug), Yutok Yönten Gönpo states that one should boil raksha in water and give the patient a handful to drink in the evening after sunset. If the patient's mind is disturbed, the text states, and his or her body becomes heavy and he or she begins to shiver, he or she has been poisoned ${ }^{54}$. Later commentators such as Kyempa Tsewang and Sangyé Gyamtso have understood the term raksha as corrupted form of ru raksha, the Tibetan term for the Sanskrit rudräkșa, the seeds of specific large evergreen trees used for prayer beads ${ }^{55}$. Others such as Lozang Chödrak (Blo bzang chos grags, 1638-1710), Könchok Chödrak (dKon mchog chos grags, 1646-1718), Karma Ngedön Tendzin Trinlé Rapgyé (b. $18^{\text {th }}$ century), and Trashibum (bKra shis 'bum, b. 1726) have interpreted raksha as an "ant" (drokma, grog ma) or "eyeless demon" (rakshamikmé, raksha mig med ${ }^{56}$ ). Lungrik Tendar (Lung rigs bstan dar, 1842?-1915) also notes in his explanation of difficult terms in the Supplement to the Instructional Tantra, a work written by Sangyé Gyamtso supplementing the Instructional Tantra of Yutok Yönten Gönpo, that there are two opinions: one that maintains raksha refers to ruruksha, and one that interprets raksha as a reference to ants ${ }^{57}$. The same statement can be found in Lungrik Tendar's work explaining the difficult expressions of the Four Tantras ${ }^{58}$.

Beside these brief descriptions, ants are rarely mentioned in Tibetan medical sources. In the early text King of the Moon (Zla ba'i rgyal po), ants are listed as an ingredient for a 
powder that is used to treat "swellings in the throat and the uvula" (gaklhok, gag lhog ${ }^{59}$ ). It can also be found in a brief treatment for "smallpox" (drum, 'brum) written by Pöntsang Yeshé (dPon tshang Ye shes, fl. $17^{\text {th }}$ century ${ }^{60}$ ). Moreover, ants were part of pills administered to drain the patient's body of fluids, as explained by Jampel Chökyi Tendzin Trinlé ('Jam dpal chos kyi bstan 'dzin 'phrin las, 1789-1838) in his work A Jewel Mine of Instructions (Man ngag rin chen 'byung gnas ${ }^{61}$ ). Given the number of potential therapies and extant medical sources, this number of descriptions is not exceedingly high. Perhaps a full survey of all available Tibetan medical texts will bring to light more results. Such an endeavour would not be a small contribution, particularly in light of the notion that ants can be used to open "channels", as maintained by Tendzin Püntsok in his A Rosary of Crystal, for which textual evidence in clinical sources is still required.

\section{Zhobur (zho sbur)}

18 The difficulties involved in the identification of Tibetan materia medica is well illustrated by the example of the zhobur insect. Its name can be literally understood as the "yogurt beetle", and Sangyé Gyamtso states that it is a small beetle that is beneficial for "yellowish fluid" diseases ${ }^{62}$. "Yellowish fluid" (chuser, chu ser) is a sticky fluid that is said to be located between flesh and skin and in the joints. It has a mixed reddishyellow colour; the red colour is a waste product of blood, and the pale-yellow colour is a refined product of "bile". If it increases or decreases it causes diseases, which are the so-called diseases of "yellow fluid ${ }^{63}$ ". Consulting the fifty-ninth chapter of the Instructional Tantra, one only finds a line where a beetle is recommended for the treatment of "yellow fluid" disease, but not a "yogurt beetle"6". In Sangyé Gyamtso's commentary, the beetle is described as a zhöbur (zhod sbur), probably a mistake for zhobur (zho sbur; see Fig. ${ }^{65}$ ). Later authors on Tibetan medicine have tried to elaborate upon this identification, with Lungrik Tendar stating that zhobur is a small and very quick beetle ${ }^{66}$. Jampel Dorjé suggests that zhobur are worms that emerge when the summer curds become stale (Fig. $7^{67}$ ). This is also Sangyé Gyamtso's interpretation of the term zhobur. Other commentators, such as Kyempa Tsewang and Trashibum, think that the term "beetle" listed in the fifty-ninth chapter of the Instructional Tantra stands for the sebur beetle ${ }^{68}$. Karma Ngedön Tendzin Trinlé Rapgyé thinks that it refers to a "black/dark golden beetle" ${ }^{69}$. Given this complicated and obscure situation, it is hardly surprising that none of the modern publications on Tibetan materia medica include the so-called "yogurt beetle".

\section{Trumembu (spru ma'i 'bu)}

The term trumembu means the "worm of the truma plant", and the truma plant is often distinguished into a white or a bright, and a black or dark type. Some sources also refer to a yellow type. In Western botany, the truma plant potentially corresponds to a wide range of plants, including the genera Heracleum, Notopterygium, Valeriana, Angelica, Thalictrum, Aralia, and Actaea ${ }^{70}$. Namgyel Drakpa Zangpo (Rnam rgyal grags pa bzang po, 1395-1475) describes the worms as being found on the white type ${ }^{71}$. Kyempa Tsewang does not say where they can be found, but only writes that the worms are multicoloured $^{72}$. Sönam Yeshé Gyentsen (bSod nams ye shes rgyal mtshan, b. $15^{\text {th }}$ century) combines both statements by saying that they live on the white truma plant and are multi-coloured $^{73}$. Lozang Chödrak elaborates upon these descriptions by writing that 
they live among the roots of the white truma plant. He states that they are multicoloured and about the size of a thumb ${ }^{74}$. Trashibum adds that they occur during autumn ${ }^{75}$. Jampel Dorjé writes that the worms live on the leaves of the white truma plant (Fig. ${ }^{76}$ ). Given the sparse nature of these desriptions, it is hardly surprising that scholars have mostly abstained from identifying the trumembu, sometimes surmising that it is the chrysalis of caterpillars, but not specifying any further ${ }^{77}$. The Translation Department of the Men-Tsee-Khang in Dharamsala has also abstained from translating the term in their English edition of the Four Tantras. They probably were unable to identify the trumembu with any degree of confidence ${ }^{78}$.

According to the Four Tantras, the trumembu stops the loss of blood of the "channels" 79 ". In other words, it stops the bleeding of a cut or injured "channel". The fact that Sangyé Gyamtso duly notes this healing potential, but does not say anything about the worm (Fig. 4) further indicates the ambiguous nature of the trumembu ${ }^{80}$. In fact, the term "worm of the truma plant" does not figure in his entire commentary, except for the occurance just mentioned. Instead, he consistenly speaks of the "seeds of truma plant" (trumemdru, spru ma'i 'bru). When discussing the truma plant, he says that these seeds are also known under name shuti (shu $\left.t i^{81}\right)$. The conflation of these two words indicates a fundamentel problem in their identification: how should one confidently differentiate the "worm of the truma plant" (trumembu) from the "seed of the truma plant" (trumemdru)?

21 In the animal section on materia medica in the Four Tantras, one finds the "worm of the truma plant" as part of animal products used for healing. The Bönpo version of the Four Tantras, the Four Hundred Thousands ('Bum bzhi), renders even this simple identification uncertain, however, because there the "seed of the truma plant" is listed". Although the Four Hundred Thousands includes the "seed" and not the "worm of the truma plant", the "seed" is still listed in the section on animal products. It seems that the conflation of these two terms frustrated some doctors, for Tendzin Püntsok clearly writes that it is a mistake to amend "worm of the truma plant" to "seed of the truma plant ${ }^{83}$ ". Consequently, he does not even mention seeds of the truma plant or bush in his Rosary of Crystal at all, but one finds "worms of the truma plant" as a materia medica of animal origin $^{84}$. Importantly, the truma plant was traditionally prescribed to stop bleeding, which is the same healing potential that these obscure worms are said to have. One might add that the dried roots of the truma plant can look like worms, which causes one to speculate that this could possibly be the origin of these "worms of the truma plant".

\section{Jelep sertra (bye leb ser khra)}

Tibetan doctors also knew of medicinal usages for butterflies, which are called "yellow mottled flat flying (insect)" (jelep sertra, bye leb ser khra), "flat flying (insect)" (chemalep, phye ma leb), and "tiger (striped) flying (insect)" (jetak, bye stag) in medical works. Butterflies are not listed in the Explanatory Tantra and therefore they are also rarely discussed in the corresponding commentaries. Again, Jampel Dorjé is the exception, for he describes the chemalep as being the yellow mottled butterfly, with a slender and small body, four wings, and colours that are so clear, it is as if they have been painted on (Figs 2, 985). In the literature on Tibetan materia medica, the chemalep is also identified as the common yellow swallowtail, the eastern pale clouded yellow, or the high-altitude butterfly, Parnassius imperator ${ }^{86}$. 
Even though the chemalep is not mentioned in the Explanatory Tantra, its medicinal use is recommended twice in the Instructional Tantra. It occurs in the chapter on diseases of the teeth, as well as the chapter discussing minor diseases, such as "twisted calf" disease (nyalok, nywa log). In the former chapter, the term "tiger (striped) flying (insect)" (jetak, bye stag) is used, and in the latter the term "tiger striped one" (taktrawo, stag khra bo). The commentators of the Instructional Tantra usually write that these terms refer to the "yellow mottled butterfly" (jelep sertra) in both cases ${ }^{87}$. Based on this actual usuage, Sangyé Gyamtso gives the healing potential of the flesh of the butterfly as curing the "tooth diseases caused by small animals" (sosin, so srin) and "twisted calf" disease ${ }^{88}$. This information is repeated by Tendzin Püntsok in his Lumps of Crystal ${ }^{89}$. In general, sosin disease is characterised by the swelling of dental roots down to the "channels" of the teeth, turning them into pus. It is so painful one cannot touch it, regardless whether the "disease caused by small animals" (sinné, srin nad) is of a hot or cold nature ${ }^{90}$. For a patient with "small animals of teeth", pain rises and abides, and the teeth ache sharply. The symptoms of "twisted calf" disease are a fine pulse and a urine having a colour like dark butter. One has headaches, painful joints, cramps in the calves, sore "channels", an upset stomach, diarrhoea, one loses one's voice, the complexion of one's face is spoiled, and one speaks nonsense like a madman ${ }^{91}$.

\section{Chagapa (cha ga pa)}

It seems that grasshoppers were also used for specific medical applications. Not many detailed descriptions of the grasshopper's appearance and habitat are found in medical works, which is perhaps due to an opinion expressed by Kyempa Tsewang that, although there exist many types of grasshoppers that can be distinguished by size and colour, they all possess the same healing potential ${ }^{92}$. Seen from this perspective, one could use any grasshopper for medicinal compounds, whatever species it may be. Most treatises just name its synonyms, such as the "one of the (cracking sound) tsaktsak" (tsaktsakpa, tshag tshag pa), the "lion cub that protects the sky"/"lion cub that jumps in the sky" (sengtruk namchong, seng phrug gnam 'phyong / mchong), and others ${ }^{93}$. Sangyé Gyamtso also provides some alternative names, as well as a brief description stating that they appear in the grassland during autumn and can fly ${ }^{94}$. Jampel Dorjé writes that chagapa are about a thumb's length, are pale brownish with black spots, and have red wings. He also states that if they soar, they make a sound, the last pair of its six legs are long, and their saliva is known as "brownish ambrosia". He concludes by stating that in China they exist in abundance and consume the harvest (Figs 3, 1095). Modern literature on Tibetan materia medica state that chagapa refers to a grasshopper, but they differ in its exact identification. Some say that it is the Oxya chinensis Thunberg, while others think it is the Patanga japonica Bolivar ${ }^{96}$.

Chagapa is not listed in the Explanatory Tantra, but it does appear in both the Instructional and Subsequent Tantras. In both cases, chagapa is used for cleansing the "channels", and in the Instructional Tantra it is mentioned in the eighty-seventh chapter on eliminating "compounded poison" (jarduk, sbyar dug). There it is part of a special three-fold treatment consisting of "gathering", "killing", and "cleansing" the poison". In the Subsequent Tantra, it is part of a very important cleansing application regarding the "channels" that forms the entire nineteenth chapter" ${ }^{98}$. The most important materia medica used in combination with the grasshopper is the jangpa beetle, which will be discussed below. Here let us merely note that the jangpa beetle is very poisonous, and it 
had to be combined with the chubur beetle (on this beetle also see below) to counteract its poisonous effect. If the latter beetle was not available, however, three heads of grasshoppers were recommended instead ${ }^{99}$.

Finally, it has also been stated that the "saliva" of grasshoppers, called "brownish ambrosia", (dütsi mukpo, bdud rtsi smug po) could be used for a head injury called "dripping brain". Nyamnyi Dorjé recommends the use of the saliva of grasshoppers for such a medicine purpose in his Ten Million Instructions. Relics, for example ${ }^{100}$. Throughout the instructions of the Tibetan medical tradition, the primary use of grasshoppers, however, was to alleviate or to neutralize the poison of the jangpa beetle. This was achieved not only by adding grasshopper heads to a medicinal preparation as mentioned above, but also by using them as an independent ingredient for the antidote in case a patient has been poisoned by a jangpa beetle ${ }^{101}$.

\section{Zindira (zi ldi ra)}

It seems that cicadas (zindira, zi ldi ra) were also used in Tibetan medicine ${ }^{102}$. None of the modern scholars writing on Tibetan materia medica discuss zindira, except those who were engaged in translating Tibetan medical sources that include this insect, such as the Four Tantras and the Blue Beryl. One reason why other authors neglect to engage this insect is probably because Yutok Yönten Gönpo does not include it in his list of materia medica in the twentieth chapter of the Explanatory Tantra. Even Tendzin Püntsok did not include zindira in the Lumps of Crystal. The only medical treatise known so far where it is mentioned is the Four Tantras of Yönten Gönpo, where it appears in the seventy-second chapter of the Instructional Tantra on paediatric diseases. There it is recommended that a particular disease called "stiff navel" (lte mkhrang) be treated with a drug that consists of the ashes made of zindi (zi ldi) and a beetle (bur, sbur), as well as the singed hair of the father and mother of the child, all cleansed in the urine of the child ${ }^{103}$. The various commentators of the Four Tantras have commented on both of these animal terms. Kyempa Tsewang wrote that zindi denotes a large beetle that is able to fly, and from which poisonous fluids emerge ${ }^{104}$. Although the meaning of the latter is uncertain, perhaps it refers to species of beetle that lives in a wet habitat, or to a species living in a burrow that is coated in fluids.

This opinion of Kyempa Tsewang is repeated by Lozang Chödrak in his commentary on the Instructional Tantra, which was arranged as the third part of Zurkhar Lodrö Gyelpo's Oral Instructions of the Forefathers (Mes po'i zhal lung ${ }^{105}$ ). Sangyé Gyamtso devotes a separate entry for zindira in his supplementary list of materia medica for the twenty-first chapter of the Explanatory Tantra (Fig. 3), and according to him, it has only one designation and no synonyms. The big cicadas emerge at the time of the summer solstice, and only one summer in every four years. The small cicadas emerge at midnight, however, and they are beneficial for diseases caused by its (poisonous) fluids and the "stiff navel" disease of children, which is of the severe type (nyen, gnyan ${ }^{106}$ ). He does not elaborate on the former type of disease, and while discussing the treament of the pediatric disease, he does not add anything ${ }^{107}$.

Later commentators were clearly influenced by the Blue Beryl, but also introduced some new information when writing about zindira. Karma Ngedön Tendzin Trinlé Rapgyé, who lived and worked in Eastern Tibet, writes that the zindi are big, dark, golden flying beetles that emerge during the summer solstice. If they move in water, poisonous fluids 
emerge from them, and they are also called "rising up crawler" (danggok, ldang gog), "soaring crawler" (dinggok, lding gog) and "zi chirping (insect)" (zi[n]dira, zi di [ldi] ra ${ }^{108}$ ). When discussing the materia medica in his work on the difficult terms in the Four Tantras, Lungrik Tendar usually quotes the Blue Beryl without any addition ${ }^{109}$, but when discussing zindira in the chapter on pediatric diseases he writes that it is a big flying beetle with antennae that emerges in places with poisonous water ${ }^{110}$. Jampel Dorjé cites both the commentary on the Instructional Tantra written by Lozang Chödrak and the commentary by Sangyé Gyamtso, followed by the observation that the big type produces a chirping sound when flying. They live on trees, are yellow-brownish, and are the size of a sebur beetle. The small type has gold on its back and is the size of a finger nail of the little finger, and they fly in masses to the desert (Fig. $8^{111}$ ). Trashibum alone gives a different statement, saying that zindi is "dog incense" or "the one of the dog incense ${ }^{112 "}$ ". It remains unclear what he means by this phrase, perhaps referring to the plants that the zindi eat.

\section{Sebur (bse sbur)}

The sebur (bse sbur) is another insect that is considered to possess healing potentials. Its name can be understood literally as "stink beetle", and it is described in some Tibetan sources as a black beetle, a stink beetle, and a black beetle with a stinking smell ${ }^{113}$. Two authors add that its back is golden ${ }^{114}$. Lozang Chödrak provides a more detailed description in his work Golden Annotations written in 1695, where he writes that there are three types: a big, a medium, and a small one. In the opinion of some, he notes, during spring they stay invisible in the ground that is exposed to the sun, and then they appear at dusk. The name of those that soar at the treetops is zindirwa (zi ldir ba), and there are two kinds of them: one big and one small. Others maintain that there are two kinds, big and small, which are called "strong wild yak of the earth" and "yak of mixed breed ${ }^{115 " . ~ J a m p e l ~ D o r j e ́ ~ a g r e e s ~ t h a t ~ t h e ~ s e b u r ~ i s ~ a ~ b e e t l e ~ o f ~ s t r o n g ~ s m e l l ~ a n d ~ a d d s ~}$ that it is black, slender, and about the size of a thumb. It has six feet, and a stinking smell comes from its anus (Fig. $12^{116}$ ). In academic literature, opinions differ regarding which beetle the sebur might be according to Western identification, but most agree that it is a species of dung beetle or a plant-feeding stink bug ${ }^{117}$.

The sebur insect is already mentioned in the King of the Moon treatise in the chapter on treating diseases of the stomach. There we learn that if sebur is mixed with garlic and then combined with water, it might have a healing effect ${ }^{118}$. When Yutok Yönten Gönpo listed animals and their healing potentials in the twentieth chapter of his Explanatory Tantras, he also included the sebur insect, stating that "sebur and jingjing tulu provide relief from the langtap (disease ${ }^{119}$ )". Langtap disease (glang thabs) can be characterised as painful cramps, which might occur together with indigestion, and which might also be caused by a disturbance of "small animals" (sin, srin) living in the human body, especially in the stomach. There are four types of langtap disease, namely one hot and one cold type, one due to disturbed internal "small animals" and one caused by "infectious fever" (nyenrim, gnyan rims ${ }^{120}$ ).

Although Yutok Yönten Gönpo provides the aforementioned instructions for the medicinal use of sebur, he does not mention sebur in the section of the Four Tantras that describes the treatment for "colic" (langtap). Despite this absence, the healing potential of sebur described in the twentieth chapter of the Explanatory Tantras is also known in 
other medical treatises ${ }^{121}$. Reviewing them, it becomes obvious that sebur can be used to treat a range of similar diseases, which are characterized by abdominal pain, indigestion, and sin diseases ( $\sin \mathrm{nad}$ ), among others ${ }^{122}$. It seems that some commentators on the Four Tantras were also aware of the discrepancy between the twentieth chapter of the Explanatory Tantras and the treatment for "colic". Therefore, some qualify the use of sebur by stating that it heals "colics" caused by "small animals" and "infectious fever ${ }^{123}$ ". Sangyé Gyamtso also provides a creative interpretation, for he dismisses the notion that sebur cures "colics" at all, and instead opines that it heals a certain type of fever called nyentsé (gnyan tshad) (Fig. 4). Nyentsé should be understood as inflammation with an increase of temperature at the affected part ${ }^{124}$, and it remains unknown how he found this healing potential. Moreover, Sangyé Gyamtso states that sebur can be used when childen have "stiff navel" disease, much like zindira mentioned above. In the corresponding paragraph of the Four Tantras, in the chapter on pediatric diseases in the Instructional Tantra, a remedy for a "stiff navel" is described that is comprised of four ingredients: namely zindi, beetle ash, and the singed hair of the father and mother, which are all to be cleansed in the child's urine ${ }^{125}$. Sangyé Gyamtso interprets "zindi and beetle ash" as ashes of both zindi and beetles, the latter of which he interprets as the "stink beetle" (sebur $\left.{ }^{126}\right)$. Therefore he dismisses the healing potential of sebur as a treatment for "colics", as given by Yutok Yönten Gönpo, and recommends sebur for treating "the stiff navel of children" instead. Some later doctors, such as Yeshé Penjor (Ye shes dpal 'byor, 1704-1788), agree and supplement traditional healing potentials found in the Four Tantras in a similar fashion ${ }^{127}$.

\section{Jingjing tulu (bying bying thu lu)}

The beetle known as jingjing tulu is described variously by different Tibetan authors. Namgyel Drakpa Zangpo, for example, writes that some authors maintain that jingjing tulu are bees, while others say they are dark red insects that can swim. He is of the opinion that jingjing tulu are actually the same as zindira (zi ldi ra ${ }^{128}$ ). Kyempa Tsewang explains that they are beetles, which smell and have a hard shell on their backs ${ }^{129}$. Lozang Chödrak states that there are at least two types: some have wings, and some do not $^{130}$. Chökyi Jungné (Chos kyi 'byung gnas, 1699/1700-1774) describes the jingjing tulu as an insect with a tail and two antennae, with a flat and wrinkly back ${ }^{131}$. Trashibum and Troru Tsenam (Khro ru Tshe rnam, 1926-2004) agree with him and give the same description ${ }^{132}$. Jampel Dorjé provides a divergent opinion, however. He states that jingjing tulu is bigger than the sebur beetle and is of a globular shape. They have six feet, have wings, and are able to fly. He also claims that they roll human faeces into round balls and carry them to their den (Figs $4,8^{133}$ ). From these descriptions, it becomes clear that different Tibetan doctors held different opinions regarding the appearance of the jingjing tulu insect. These different opinions have also influenced the identifications made in the modern academy, for some scholars think that the jingjing tulu is a dung beetle, while others write that it is a stink bug. A third group identifies the jingjing tulu as a wingless cockroach ${ }^{134}$.

When listing materia medica and their healing potentials in the twentieth chapter of the Explanatory Tantra, Yutok Yönten Gönpo names sebur and jingjing tulu together as having the potential to cure the langtap disease, or "colics ${ }^{135 " . ~ S i m i l a r ~ t o ~ s e b u r, ~ h o w e v e r, ~}$ jingjing tulu is not mentioned in the corresponding paragraphs of the Instructional Tantra. In other words, such a healing potential is maintained in the Explanatory Tantra 
but not actually recommended in the Instructional Tantra. Also much like the case of sebur, medicinal prescriptions of jingjing tulu are also known in other medical treatises. For instance, jingjing tulu is a part of a drug compound that is used to cure "colics" in the King of the Moon treatise ${ }^{136}$. The jingjing tulu beetle occurs six times in the Ten Million Instructions: Relics written by Nyamnyi Dorjé, and in five cases it prescribed to alleviate "colics". Jampel Chökyi Tendzin Trinlé also mentions jingjing tulu for the same medicinal purpose in his A Jewel Mine of Instructions ${ }^{137}$. Furthermore, this beetle is also employed to cure patients having difficulties with urinating, as explained in the fiftyfourth chapter of the Instructional Tantra ${ }^{138}$.

\section{Chubur (chu sbur)}

The chubur beetle is traditionally said to treat problems with urination ${ }^{139}$. Its name literally means "water beetle", and sometimes it is also called the "quick beetle" (burgyok, sbur mgyogs ${ }^{140}$ ). Usually it is described as a small black beetle that moves quickly in water (Fig. $4^{141}$ ), and Jampel Dorjé adds that it develops from rain water and transforms into a small frog when it gets old. It is also called "one life two bodies" and the "frog with a tail", because later it is said to become a frog (Fig. 11 ${ }^{142}$ ). Thus, it is obvious that Jampel Dorjé has conflated two animals: a beetle and a frog that is in its larval stage of a tadpole. The names in Mongolian, Manchu, and Chinese also are terms for tadpole ${ }^{143}$. Modern scholars usually identify chubur as a water beetle ${ }^{144}$, and, as mentioned above, it is usually prescribed for patients who have difficulties urinating. It occurs in a remedy to treat an illness characterised by acute pain and urinary problems ${ }^{145}$. In addition, it can also be found in the chapters of the Four Tantras dealing with the treatment for "compounded poison" (jarduk, sbyar dug) and of "non-poisonous substances that have turned into poison" (gyurduk, gyur dug). Sangyé Gyamtso provides another special application of the beetle for gently cleansing diseases of the "channels ${ }^{146 "}$. Regardless, it seems that its basic use was for removing problems with the flow of urine, as the treatise of Jampel Chökyi Tendzin Trinlé indicates ${ }^{147}$.

\section{Jangpa (byang pa)}

The jangpa beetle is generally identified in modern literature as a blister beetle, Mylabris phalerata Pallas or Mylabris cichorii Fabricius ${ }^{148}$. The jangpa beetle has various alternative names in Tibetan, however, such as pemé (padme), "Chinese wheel of fire tongues", "small tiger lotus", "golden Mongolian cushion", "red striped small tiger", "hero of women diseases", and others ${ }^{149}$. Traditionally Tibetan doctors have classified the beetles as black or black striped, red striped, and gold striped (Figs 4, 13 ${ }^{150}$ ). They are said to possess a varying degree of quality, beginning with the black one, which has a superior quality; the black and red striped ones, which have a medium quality; and the golden striped one, which has an inferior quality. Some doctors were of the opinion that one should not use the first type, the black one, because it is poisonous ${ }^{151}$. The black jangpa is not used by Yutok Yönten Gönpo in the Four Tantras, for example, and consequently many treatises just distinguish between two types of jangpa beetles: namely the red striped ones and the gold striped ones. The former is said to be of good quality and the latter of poor quality. This order of potency also found its expression in the number of insect equivalents. Sönam Yeshé Gyemtsen, for example, writes that 
three black beetles are equivalent to seven red striped beetles, and seven red striped beetles equal eleven gold striped beetles ${ }^{152}$. being used. It is also usually said that the inner transparent wings should be removed, as they contain poison ${ }^{153}$. Regardless, Darma Gönpo (Darma mgon po, fl. $13^{\text {th }}$ century) writes that some doctors say that one should cut off the head and the legs of the jangpa beetle. He remarks that, in his opinion, one should not cut them off, however, because if the have no head and legs they cannot pull out whatever disease they are being used to treat ${ }^{154}$. This opinion is shared by Yutok Yönten Gönpo in his Four Tantras ${ }^{155}$. Nyamnyi Dorjé states that if the jangpa beetle is without wings, it will be sharp and quick ${ }^{156}$. On a semantic level, using beetles to cleanse the "channels" can be understood as sending the beetles through the "channels" to pull out disease-causing agents. Mipam Gyamtso (Mi pham rgya mtsho, 1846-1912), for example, cites Yutok Yönten Gönpo in describing the jangpa beetle as driving the disease through the channels ${ }^{157}$. This basic meaning may also be seen in a brief treatment for cleansing the "channels" contained in the Big Measure of Gold (gSer bre chen mo), which was probably compiled by Drangti Penden Gyeltsen (Brang ti dPal ldan rgyal mtshan, fl. $14^{\text {th }}$ century). The treatment reads:

Seven striped lice without wings (i.e. the striped jangpa beetle) ride on the (yellow) "quick beetle", holding a wheel of iron ${ }^{158}$ (and) a club of conch-shell (i.e. sal ammoniac) in their hands, (and wearing) a hat of gold (i.e. fresh sand), finely ground. One should give (this compound) with beer through a younger male relative ${ }^{159}$.

One can probably assume that such compounds, which contained a manageable number of ingredients, were more common than the very elaborate treatments outlined in the Subsequent Tantra. Reviewing the medical literature, one finds several instances where the jangpa beetle was used to cleanse the "channels", and it is mentioned several times in this regard as early as the King of the Moon treatise ${ }^{160}$. Sönam Rinchen (bSod nams rin chen, 1079-1153) sees jangpa beetles as an important ingredient in drugs used to cleanse the "channels ${ }^{161}$ ". Darma Gönpo gives a very detailed discussion that should be compared to the Yönten Gönpo's description in the Subsequent Tantra ${ }^{162}$. Jangpa beetle prescriptions are also found in the collection of medical treatises named A Fist of Hundred Thousands ('Bum khu tshur) that mainly consists of works recorded by Chakmen Ringyel (Phyag sman Rin rgyal, ca. $15^{\text {th }}$ century). Both treatises represent lineages of knowledge that was handed down in the Cherjé (Cher rje) and Chakmen (Phyag sman) medical schools, respectivly ${ }^{163}$. The same can be said about the Drangti (Brang ti) school, for in addition to the aforementioned formula attributed to Penden Gyeltsen, compounds containing jangpa beetles can also be found in the The Measure of Silver (dNgul bre) that was probably authored by Dorjé Pelzang (Rdo rje dpal bzang), who flourished during the $15^{\text {th }}$ and $16^{\text {th }}$ centuries ${ }^{164}$. In the $15^{\text {th }}$ century, the cleansing of the "channels" by jangpa beetles is also found in the medical writings of Namgyel Drakpa Zangpo and Nyamnyi Dorjé ${ }^{165}$. These works clearly represent the traditions of later medical schools, the Jangluk (Byang lugs) and the Zurluk (Zur lugs), respectively. Cleansing the "channels" with jangpa beetles was also known in later times, as the works of Yeshé Penjor show ${ }^{166}$. Thus, it is obvious that this therapy was of great importance for generations of Tibetan doctors ${ }^{167}$.

Instead of providing an overview of cleansing the "channels", however, here we shall consider how a doctor decided whether a jangpa beetle is of good or poor quality. It seems that this method can be traced back to Jinamitra, possibly the father of Kyebu

Études mongoles et sibériennes, centrasiatiques et tibétaines, 50 | 2019 
Melha (Skyes bu Me lha, fl. $11^{\text {th }}$ century $\left.{ }^{168}\right)$. There are four criteria that are considered in this process: namely (1) the type of jangpa beetle, (2) the season in which they were collected, (3) the locality, and (4) the way in which they were killed, all of which are addressed by Yutok Yönten Gönpo, Darma Gönpo, the anonymous author whose work is included in the A Fist of Hundred Thousands, and Tendzin Püntsok ${ }^{169}$. As mentioned above, beetles that have red stripes are of good quality, but if they have gold stripes, they are considered to be of poor quality. The best time to collect jangpa beetles is autumn, the first month of autumn in particular, when the rainy season has ended. They should be collected among the sema plant ( $\operatorname{sad} m a$ ) and the thorns of the kyiwa plant (skyi ba), especially if they have died suddendly ${ }^{170}$. If one collects beetles at the end of spring and during the rainy season, when they have been frozen following the rains, they are of poor quality. The same applies to beetles living among the leaves of the yokmo shrub (yog mo) and that have died naturally or have been injured ${ }^{171}$.

\section{Concluding remarks}

It is evident that animals and their by-products were an integral part of Tibetan medicine, even though it is not possible to provide a precise quantitative analysis. For this, one would have to carry out a survey of the Tibetan materia medica that are used in drugs and other therapies ${ }^{172}$. This is by no means the only unresolved issue in our current knowledge of the use of animals in Tibetan medicine.

41 Certainly, one must also critically question the currently available publications on Tibetan materia medica, for they are generally not based on appropriate studies of materia medica terminology. Some authors just copy identifications that are given in previous works, and very often the proposed Western identification is influenced by or borrowed from the established identification of Chinese materia medica. This does not just concern insects studied in this article but concerns animals used in Tibetan medicine in general ${ }^{173}$.

In some cases, the actual existence of the proposed animal or insect and its medicinal application remains unclear and more information would be necessary for proper identification. This applies to the zhobur insect, for example, as well as the trumembu. The use of ants also needs further inquiry, for although ants populate the Himalayan regions, Tibet, and Mongolia ${ }^{174}$, further research would be needed to determine which species are used and whether ants are indeed used by Tibetan doctors at all. It is known that ants are used for medicinal purpose in regions adjacent to Tibet, however, such as Mongolia and China ${ }^{175}$. A thorough comparision of the insects used in the Chinese medical tradition could help elucidate the insects that are used in Tibetan medicines. Such research would go well beyond the scope of this preliminary study, however, as it would require the analysis of compounded drugs, and not just single ingredients, based on a systematic survey of the relevant Chinese medical sources. Thus, it might be interesting to see which butterflies, or more likely their catarpillars, were used in Chinese medicine to treat stomach diseases. Also, the use of the cicada slough for paediatric ailments and other illnesses should be analysed in future research ${ }^{176}$. Possibly these very specific applications of insects in Tibetan medicine could demonstrate a Chinese influence in the medical system of the neighbouring country. chinensis Dallas or Eupolyphaga sinensis Walker, is specifically given in case of colics". In 
modern Chinese medicine, one of the medicinal applications of Aspongopus chinensis Dallas alias Coridius chinensis Dallas (九香蟲) can be to alleviate stomach pain and treat gastrointestinal diseases ${ }^{177}$. Moreover, the use of the shadrang fly appears to have a Chinese background, for it seems that there is no use in the Tibetan medical tradition other than as an ingredient for "restoring virility". Notably, Nyamnyi Dorjé states that this particular remedy represents the instructions of the king of the eastern capital in China ${ }^{178}$. In other words, such uses of the shadrang fly might be a Chinese remedy that was integrated into Tibetan medicine. Insects such as horseflies are well-known in Chinese medicine and are the subject of current academic research ${ }^{179}$. Perhaps there also is a Chinese background for the medicinal use of the jangpa beetle in Tibet, but it could also be a feature that has not been borrowed, but is shared by both medical systems. In sum, the number of medicinal insects in Tibetan medicine is limited, and their uses are very specific. Perhaps this degree of specificity indicates origins and influences from neighbouring medical traditions.

Figure 1. An anthill (edited)

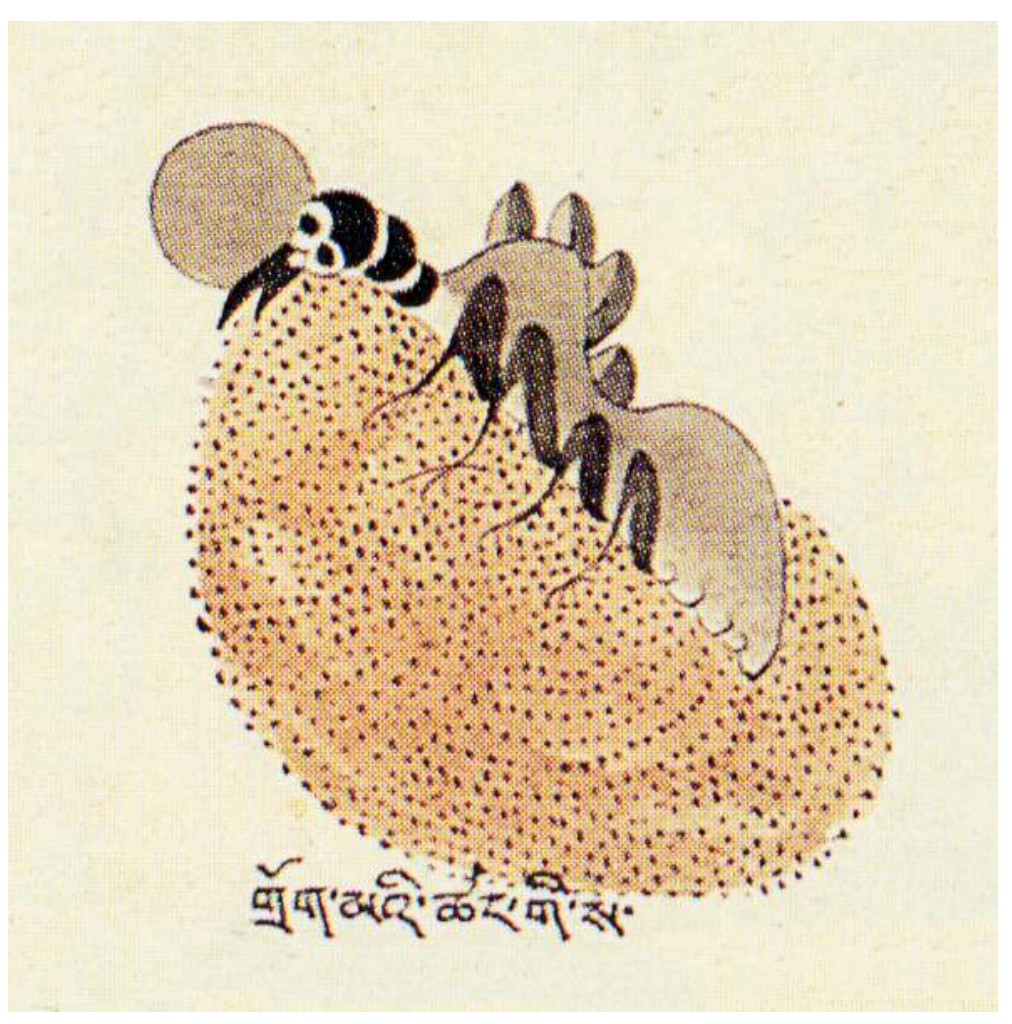

(c) After Parfionovitch (Parfionovitch et al. 1992, pl. 30) 
Figure 2. The jetak butterfly and the zhobur insect (from left to right) (edited)

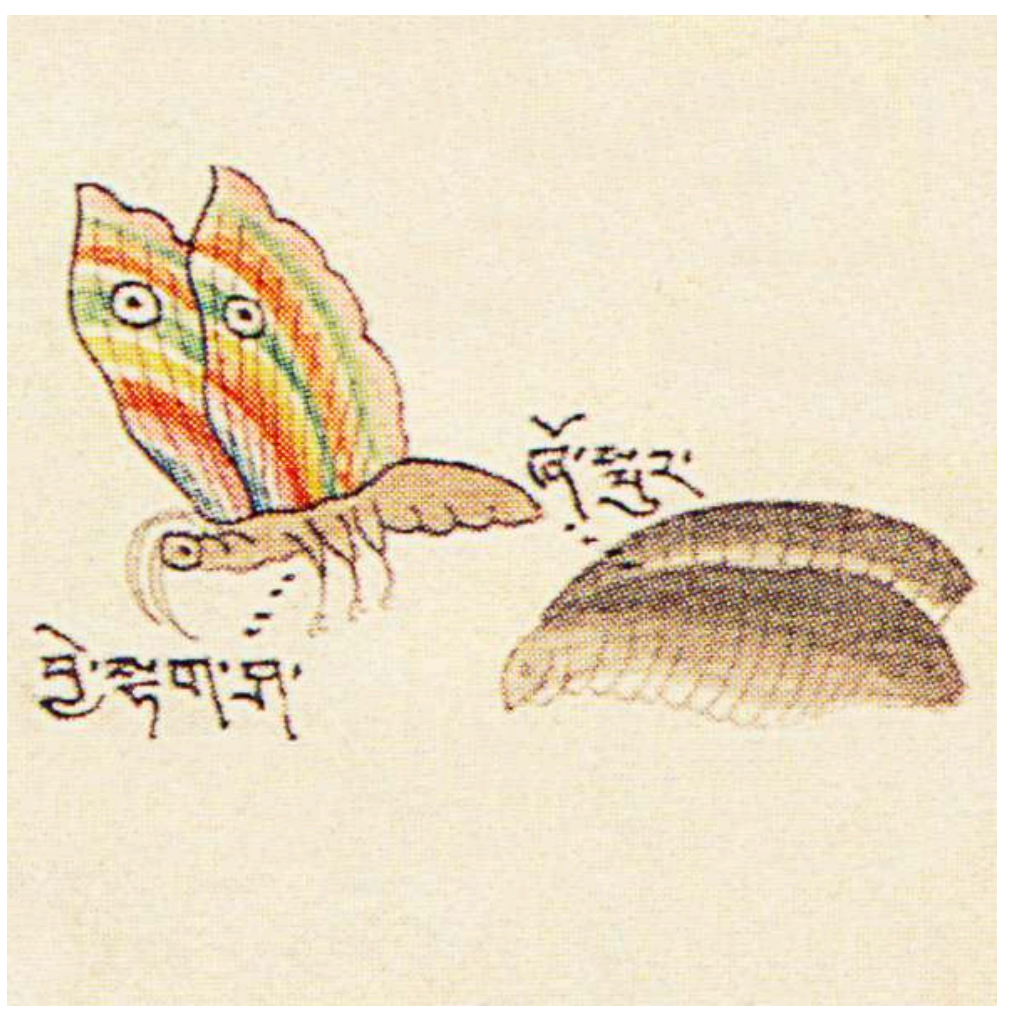

(c) After Parfionovitch (Parfionovitch et al. 1992, pl. 31)

Figure 3. The small and big zindira insect and the chagapa grasshoper (from left to right) (edited)

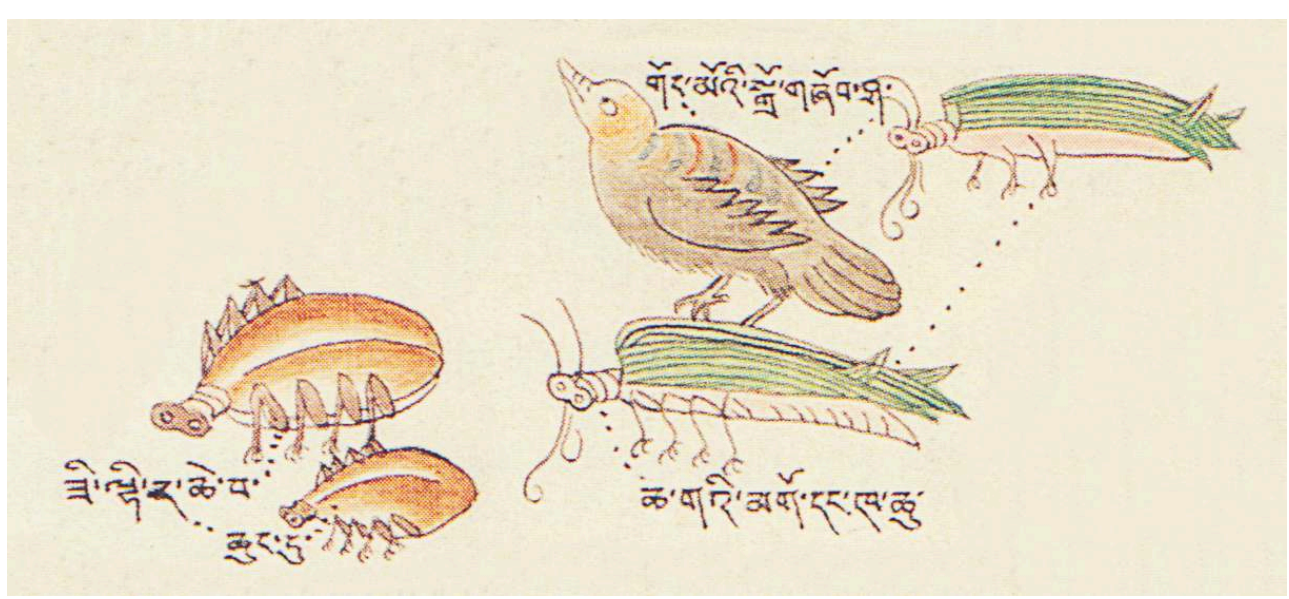

(C) After Parfionovitch (Parfionovitch et al. 1992, pl. 31) 
Figure 4. The jangpa beetle, the diksin crab, the chubur beetle (above), the sebur beetle (below), the jingjingtulu beetle/bug and the truma worm (from left to right) (edited)

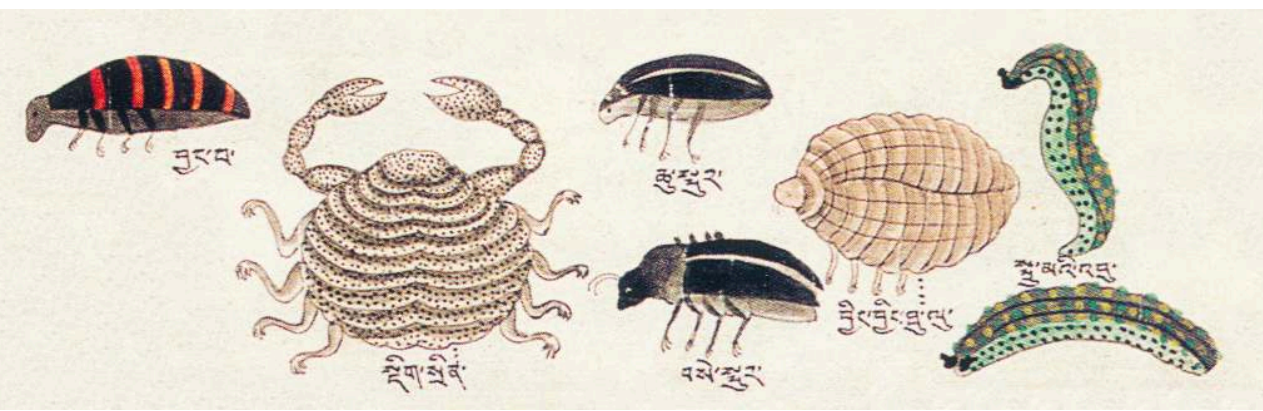

(c) After Parfionovitch (Parfionovitch et al. 1992, pl. 28)

Figure 5. The kalanta bird (edited)

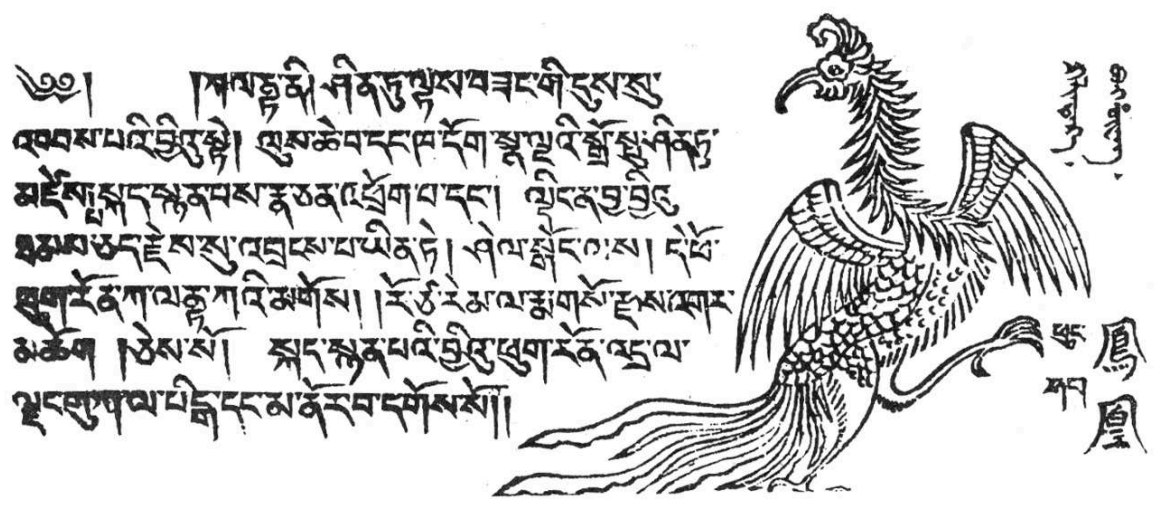

(c) After Lokesh Chandra 1971, p. 223

Figure 6. The drokma ant (edited)

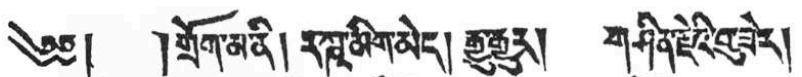

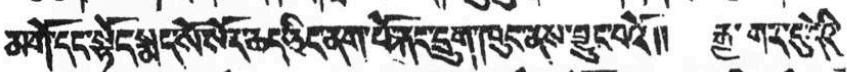

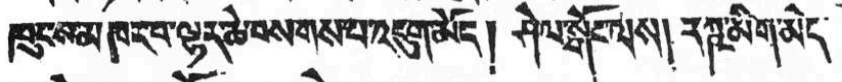

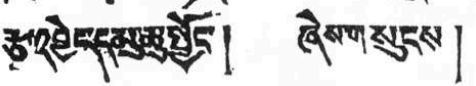

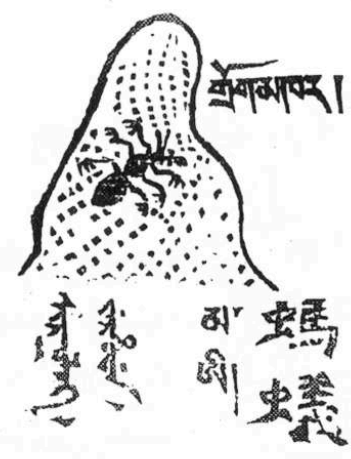


Figure 7. The truma worm and the zhobur insect (edited)

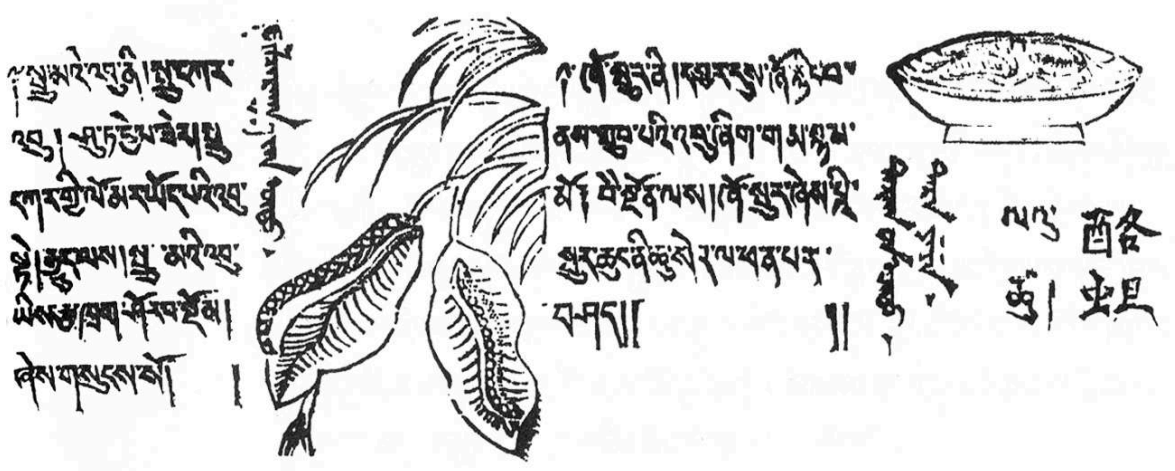

Figure 8. The jingjingtulu beetle / bug and the zindira insect (From left to right) (edited)

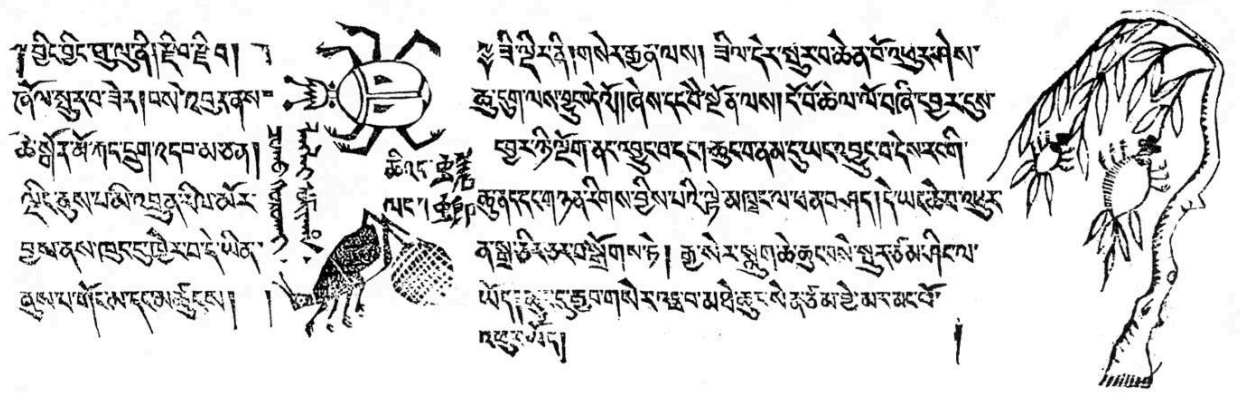

(c) After Lokesh Chandra 1971, p. 255

Figure 9. The chemalep butterfly (edited)

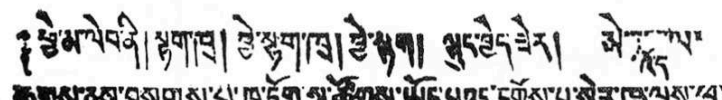

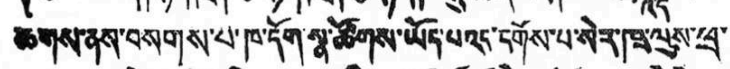

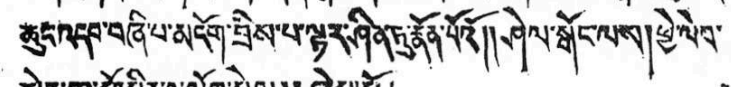

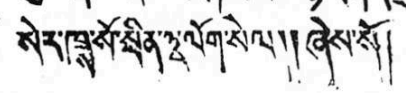

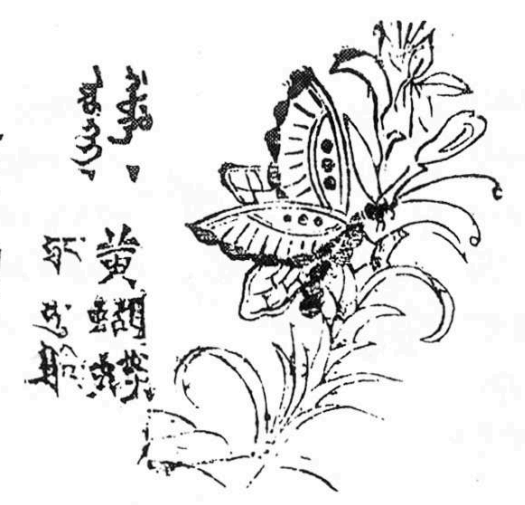

(c) After Lokesh Chandra 1971, p. 256 
Figure 10. The chagapa grasshoper (right) (edited)

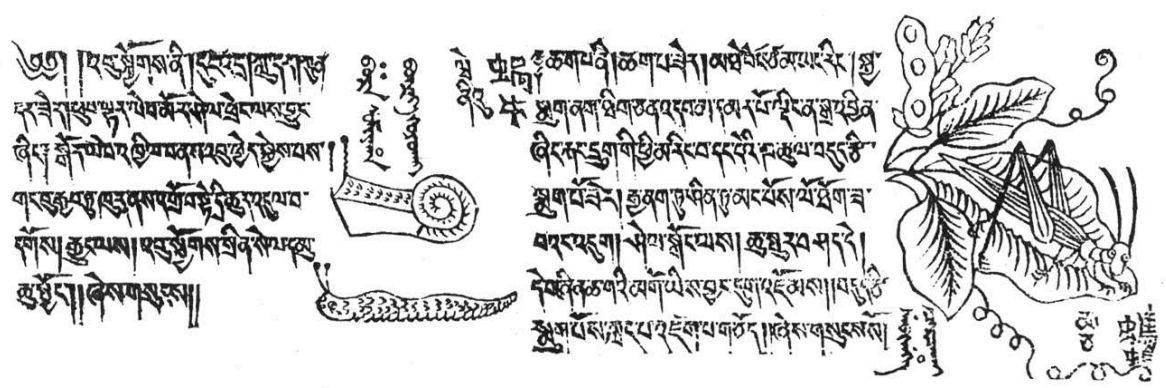

(c) After Lokesh Chandra 1971, p. 263

Figure 11. The chubur beetle (left) (edited)

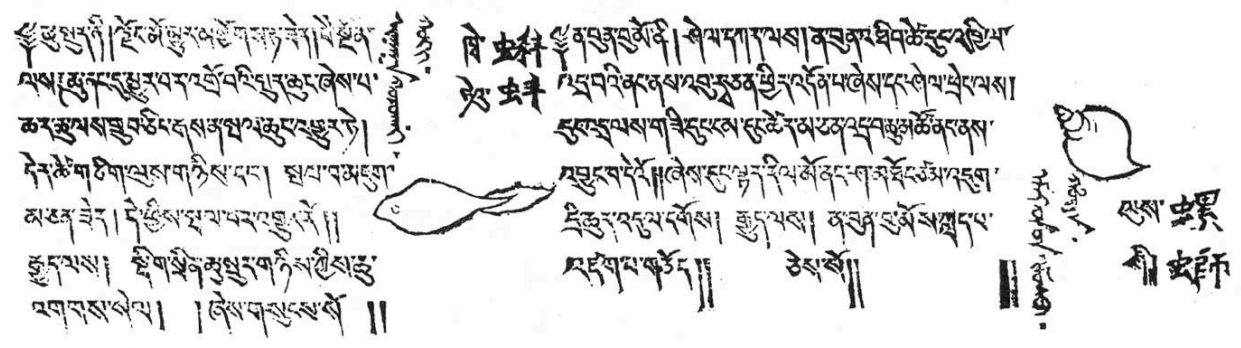

Figure 12. The sebur beetle (far right) (edited)

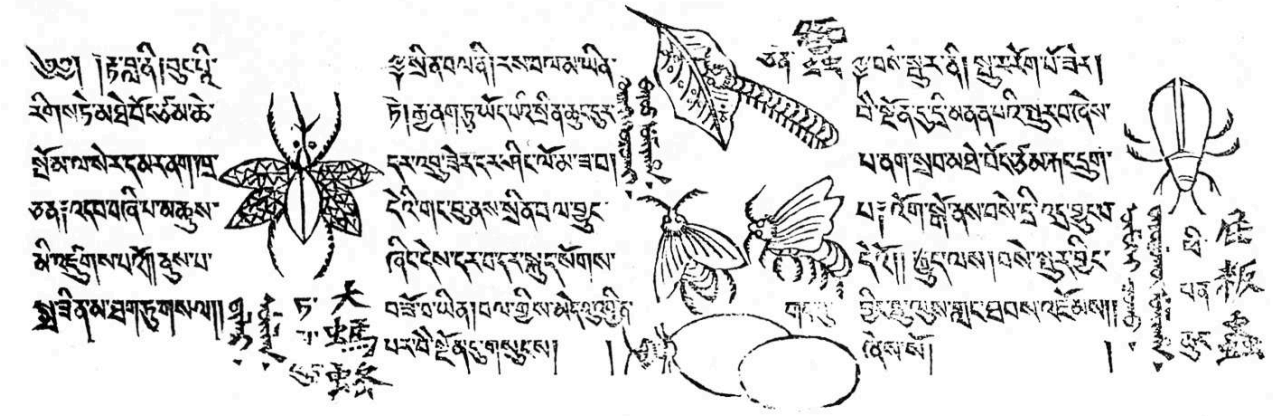




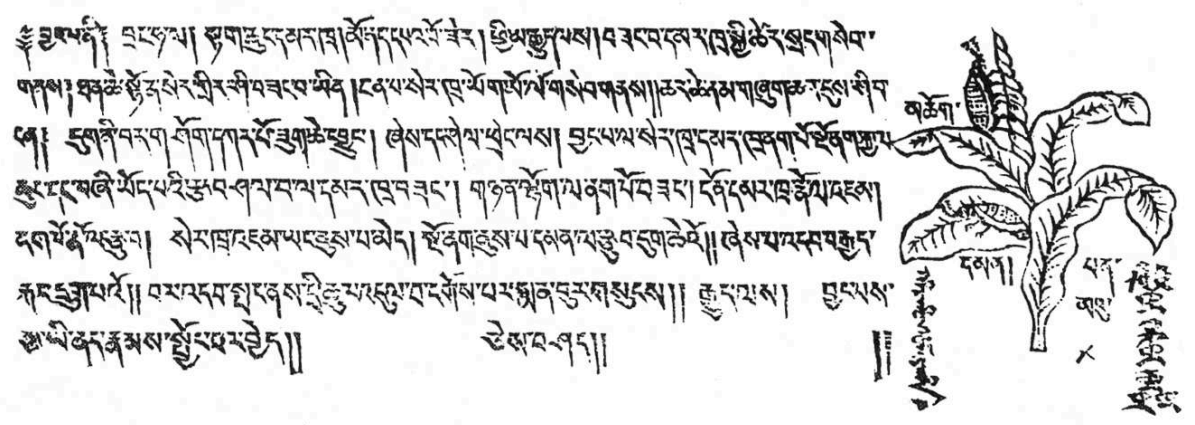

\section{BIBLIOGRAPHY}

\section{Primary sources}

\section{A ru ra'i phreng ba'i mdzes rgyan I}

Lung rigs bstan dar 1986 rGyud bzhi'i brda bkrol rnam rgyal a ru ra'i phreng ba'i mdzes rgyan [Explanation of Termini technici in the four tantras. A beautiful garland of all-victorious Myrobalan] (Lha sa, Mi rigs dpe skrun khang).

\section{A ru ra'i phreng ba'i mdzes rgyan II}

Lung rigs bstan dar 2005 rGyud bzhi'i brda' bkrol rnam rgyal a ru ra'i phreng ba'i mdzes rgyan [Explanation of Termini technici in the four tantras. A beautiful garland of all-victorious Myrobalan] (Pe cin, Mi rigs dpe skrun khang).

\section{bDud rtsi sgron me}

mNyam nyid rdo rje 2007 rGyud rgyal bdud rtsi snying po las rgyud phyi ma'i sman ngo gsal byed bdud rtsi sgron me [An explanation on the identification of materia medica in the subsequent tantra of the "King of tantras. The essence of ambrosia". A lamp of ambrosia], in dPal brtsegs Bod yig dPe rnying Zhib 'jugs khang (ed.), gSo rig sman gyi ro nus ngos 'dzin gsal ston phyogs sgrig rin chen sgron me [A compilation clarifying the taste, healing potential and identification of materia medica. A precious lamp] (Pe cin, Krung go'i bod rig pa dpe skrun khang), pp. 249-280.

\section{bDud rtsi'i chu rgyun}

Byang pa rNam rgyal grags pa bzang po 2001 Bshad rgyud kyi 'grel chen bdud rtsi'i chu rgyun [A great commentary of the explanatory tantra. A stream of ambrosia] (Khreng tu'u, Si khron mi rig dpe skrun khang).

\section{bDud rtsi'i thigs pa}

Ye shes dpal 'byor 2007 gSo ba rig pa'i man ngag shin tu nyung 'dus bdud rtsi'i thigs pa [Very brief medical instructions. Drops of ambrosia], in Ye shes dpal 'byor, Sum pa'i sman yig phyogs 
bsgrigs [A compilation of the Medical Writings of Sumpa] (Pe cin, Mi rigs dpe skrun khang), pp. 401-494.

\section{'Bum bzhi}

Dpyad bu khri shes 1999 gSo rig bdud rtsi'i bang mdzod 'bum bzhi [The four collections of ambrosia treasures of medicine] (New Delhi, Paljor Publications).

\section{'Bum khu tshur}

Si khron zhing chen rnga ba khul bod yig rtsom sgyur cus (ed.) 2004 'Bum khu tshur [A fist of hundred thousands] (Pe cin, Mi rigs dpe skrun khang).

\section{Bye ba ring bsrel}

Mnyam nyid rdo rje 1993 Man ngag bye ba ring bsrel [Ten million instructions. Relics] (Lan kru'u, Kan su'u mi rigs dpe skrun khang).

\section{'Chi med nor bu'i phreng ba}

Karma nges don bstan 'dzin 'phrin las rab rgyas 2008 gSo rig yan lag brgyad ldan chu gter las gces bsdus 'chi med nor bu'i phreng ba [A precious collection. The jewel garland of immortality from the "Ocean of medicine in eight branches"], in Karma nges don bstan 'dzin 'phrin las rab rgyas, Karma ratna'i sman yig gces btus [The precious collection of Karma Ratna's medical writings] (Pe cin, Mi rigs dpe skrun khang), pp. 3-82.

\section{dNgul bre ma}

dPal ldan rgyal mtshan 2004 Sa skya sman grong ba'i man ngag thun mong ma yin pa dngul bre $\mathrm{ma}$ [The silver measure of extraordinary instructions of the Sakya medical house], in Dpal ldan rgyal mtshan, Man ngag gser bre ma dang dngul bre ma [The gold measure and silver measure of instructions] (Pe cin, Mi rigs dpe skrun khang), pp. 86-303.

\section{Don gsal nyin byed}

Rin chen 'od zer 2001 bDud rtsi snying po yan lag brgyad pa gsang ba man ngag gi rgyud las dum bu gnyis pa bshad pa'i rgyud kyi 'bru 'grel don gsal rab tu snang ba'i nyin byed [A word by word commentary of the explanatory tantra, the second part of the "Essence of ambrosia. The tantras of secret instructions on the eight branches". A sun fully illuminating the clear meaning], in Rin chen 'od zer, bDud rtsi snying po yan lag brgyad pa gsang ba man ngag gi rgyud las rtsa rgyud dang bshad rgyud kyi 'grel pa [The commentaries of the fundamental tantra and the explanatory tantra of the 'Essence of ambrosia. The tantras of secret instructions on the eight eranches'] (Khreng tu'u, Si khron mi rig dpe skrun khang), pp. 53-427.

\section{Drang srong zhal lung}

Khro ru Tshe rnam 2001 bDud rtsi snying po yan lag brgyad pa gsang ba man ngag rgyud kyi 'grel chen drang srong dgyes pa'i zhal lung las bshad rgyud kyi 'grel pa [The commentary of the explanatory tantra from the "Great commentary on 'The essence of ambrosia. The tantras of secret instructions on the eight branches'. Oral instructions to delight the seers"], in Khro ru Tshe rnam, gSo rig rgyud bzhi'i 'grel chen drang srong zhal lung [The great commentary on the four medical tantras. Oral instructions of seers] (Khreng tu'u, Si khron mi rigs dpe skrun khang).

\section{Dri med kun gsal}

bSod nams ye shes rgyal mtshan 2002 dPal ldan bshad pa'i rgyud kyi 'grel pa bklag pas don thams cad grub pa'am 'grel chen dri med kun gsal [A commentary on the glorious explanatory tantra. Accomplishing all purposes by reading or the great commentary. A stainless mirror] (Khreng tu'u, Si khron mi rigs dpe skrun khang).

\section{Dug srung rim pa}

bsTan 'dzin phun tshogs 2006 Dug srung gi rim pa yang zab rdo rje'i srog rdzong [The most profound steps for guarding against poison. An indestructable life-force fortress], in bsTan 'dzin 
phun tshogs, De'u dmar gso rig gces btus, vol. 1 [The precious medical collection of deumar] (Pe cin, Mi rigs dpe skrun khang), pp. 466-481.

\section{gCes bsdus phan bde'i snying po'i zhal shes}

Anonymus 2008 gCes bsdus phan bde'i snying po'i zhal shes man ngag rim pa gsal bar bkod pa bzhugs dbu yi gzigs phyogs [An initial work entitled oral advice on "A precious collection. The essence of happiness and well-being" with a clearly arranged order of instructions], in 'Bri gung Chos grags et al., 'Bri gung sman rtsis phyogs bsgrigs [A compilation of the medical and astrological writings of the 'Bri gung school] (Pe cin, Mi rigs dpe skrun khang), pp. 414-427.

\section{gSer bre chen mo I}

Bod rang skyong ljongs sman rtsis khang (ed.) 2005 Brang ti lha rje'i rim brgyud kyi man ngag gser bre chen mo [Instructions of the lineal transmission of the drangti physicians. A big golden measure] (Lha sa, Bod ljongs mi dmangs dpe sku khang).

\section{gSer bre chen mo II}

Anonymous 2004 Brang ti lha rje'i rim brgyud kyi man ngag gser bre chen mo [Instructions of the lineal transmission of the Drangti physicians. A big golden measure], in Shes rab rin chen et al., gSo rig [XXX] (Pe cin, Mi rigs dpe skrun khang), pp. 33-296.

\section{gSer gyi thur ma}

Blo bzang chos grags 2005 bShad rgyud kyi sdong 'grems legs bshad gser gyi thur ma [A fine explanation of the unfolded trees of the explanatory tantra. A golden stylet], in Blo bzang chos grags, Legs bshad gser gyi thur ma bka' phreng mun sel sgron me [The fine explanation. A golden stylet. A rosary of precept. A lamp dispelling darkness] (Pe cin, Mi rigs dpe skrun khang), pp. 1-143.

\section{gSer mchan}

Blo bzang chos grags $2006 \mathrm{gSer}$ mchan rnam bkra gan mdzod [Variegated golden explanatory notes. A miscellaneous storehouse ] (Pe cin, Mi rigs dpe skrun khang).

\section{gSung sgros}

bSod nams rin chen 2005 gSung sgros phan byed rig pa'i mdzod [The oral lecture. A treasury of knowledge to benefit]. A treasure collection of medical practices from the tradition of Sgam po pa Bsod nams rin chen (1079-1153) (Delhi, Tashi Y. Tashigang).

\section{gZhan la phan gter}

Padma dkar po 1973-1974 rGyud bzhi'i 'grel pa gzhan la phan gter [A commentary of the four tantras. A mine to benefit others], in Padma dkar po, gSung 'bum, vol. 1 [Collected works] (Darjeeling, Kargyud sungrab nyamso khang), pp. 325-476.

\section{Kun gsal snang mdzod}

bsTan 'dzin phun tshogs 2007 Lag len gces rigs btus pa sman kun bcud du sgrub pa'i las kyi cho ga kun gsal snang mdzod [A selection of most important practices. Practical methods to extract the essence of every medicine. A brilliant illumination], in bsTan 'dzin phun tshogs, De'u dmar gso rig gces btus [The precious medical collection of Deumar], vol. 2 (Pe cin, Mi rigs dpe skrun khang), pp. 760-843.

\section{Man ngag lhan thabs}

Sangs rgyas rgya mtsho 1991 Man ngag lhan thabs [Supplement to the instructional tantra] (Zi ling, Mtsho sngon mi rigs dpe skrun khang).

\section{Man ngag lhan thabs brda bkrol}

Bod ljongs bod lugs gso rig zhib 'jug khang (ed.) 2008 Man ngag lhan thabs kyi brda bkrol rnam rgyal gser mdog gi phreng ba [Explanation of termini technici in the Supplement to the instrcutional 
tantra. A beautiful garland of all-victorious and golden myrobalan] (Lha sa, Bod ljongs mi dmangs dpe skrun khang).

\section{Man ngag rin chen 'byung gnas}

'Jam dpal chos kyi bstan 'dzin 'phrin las 1997 gSo rig gi bstan bcos mtha' dag gi snying po rnams phyogs gcig tu bsdus pa man ngag rin chen 'byung gnas [The central meaning of all medical treatises compiled into one. A treasure mine of instructions] (Zi ling, Mtsho sngon mi rigs dpe skrun khang).

\section{Man ngag snying gi nor bu}

Karma nges don bstan 'dzin 'phrin las rab rgyas 2008 gCes bsdus 'chi med nor phreng las man ngag snying gi nor bu [instructions. A heart jewel from "A precious collection. The jewel garland of immortality"] , in Karma nges don bstan 'dzin 'phrin las rab rgyas, Karma ratna'i sman yig gces btus [The precious collection of Karma Ratna's medical writings] (Pe cin, Mi rigs dpe skrun khang), pp. 83-150.

\section{mDzes mtshar mig rgyan A I}

'Jam dpal rdo rje 1971 gSo byed bdud rtsi'i 'khrul med dngos 'dzin bzo rig me long du rnam par shar pa mdzes mtshar mig rgyan [The arts of correct identification of medical ambrosia clearly appearing in a mirror. An eye adornment of beauty and marvel], in Lokesh Chandra (ed.) An Illustrated Tibeto-Mongolian Materia Medica of Ayurveda of 'Jam-dpal-rdo-rje of Mongolia (New Delhi, International Academy of Indian Culture), pp. 1-174.

\section{mDzes mtshar mig rgyan A II}

'Jam dpal rdo rje 2008 gSo byed bdud rtsi'i 'khrul med dngos 'dzin bzo rig me long du rnam par shar pa mdzes mtshar mig rgyan [The arts of correct identification of medical ambrosia clearly appearing in a mirror. An eye adornment of beauty and marvel], in 'Jam dpal rdo rje gSo byed mdzes mtshar mig rgyan [Medicine. An eye adornment of beauty and marvel] (Pe cin, Mi rigs dpe skrun khang). pp. 1-325.

\section{mDzes mtshar mig rgyan B I}

'Jam dpal rdo rje 1971 Dri med shel phreng nas bshad pa'i sman gyi 'khrungs dpe mdzes mtshar mig rgyan [Sample book of materia medica as explained by the "Stainless crystal rosary of materia medica". An eye adornment of beauty and marvel], in Lokesh Chandra (ed.) An illustrated Tibeto-Mongolian materia medica of Ayurveda of 'Jam-dpal-rdo-rje of Mongolia (New Delhi, International Academy of Indian Culture), pp. 1-24.

\section{mDzes mtshar mig rgyan B II}

'Jam dpal rdo rje 2008 Dri med shel phreng nas bshad pa'i sman gyi 'khrungs dpe mdzes mtshar mig rgyan [Sample book of materia medica as explained by the "stainless crystal rosary of materia medica". An eye adornment of beauty and marvel], in 'Jam dpal rdo rje gSo byed mdzes mtshar mig rgyan [Medicine, an eye adornment of beauty and marvel] (Pe cin, Mi rigs dpe skrun khang). pp. 325-491.

\section{Mes po'i zhal lung sMad cha}

Dar mo sman rams pa and rNam gling pan chen 2005 rGyud bzhi'i 'grel pa mes po'i zhal lung. sMad cha [A commentary of the four tantras. Oral instructions of the fore-fathers. Second volume] (Pe cin, Mi rigs dpe skrun khang).

\section{Mes po'i zhal lung sTod cha}

Zur mkhar Blo gros rgyal po 2005 rGyud bzhi'i 'grel pa mes po'i zhal lung. sTod cha [A commentary of the four tantras. Oral instructions of the fore-fathers. First volume] (Pe cin, Mi rigs dpe skrun khang). 


\section{mGul rgyan}

bsTan 'dzin phun tshogs 2007 Sna tshogs man ngag nyer lnga brgya rtsa 'chi med bdud rtsi shel dkar phreng ba mkhas mang yongs kyi mgul rgyan [Ambrosia of immortality of twenty-five hundreds instructions for various diseases. A necklace of white crystal. A supreme neck ornament for all scholars], in bsTan 'dzin phun tshogs, De'u dmar gso rig gces btus, vol. 2 [The precious medical collection of Deumar] (Pe cin, Mi rigs dpe skrun khang), pp. 705-759.

\section{mKhas pa'i zhal lung}

Gling sman bKra shis 'bum 2004 gSo ba rig pa'i bstan bcos chen po dpal ldan rgyud bzhi'i dka' 'grel mkhas pa'i zhal lung [The great medical treatise. Commentary on difficult points of the famous four tantras. The oral instrction of scholars], in Dam chos zla ba (ed.), gSo rig [Medicine] (Zi ling, Mtsho sngon mi rigs dpe skrun khang), pp. 123-710.

\section{Nyi ma'i snying po}

bsTan 'dzin phun tshogs 2007 Bshal skyugs dang rtsa sbyong gi lag len rgyud kyi dgongs pa gsal bar byed pa'i zhal gdams zin bris nyi ma'i snying po [Notes on oral instructions that explain the intention of the four tantras on the practice of laxatives, emetics and cleansing the channels. The orb of the sun], in bsTan 'dzin phun tshogs, De'u dmar gso rig gces btus [The precious medical collection of Deumar], vol. 2 (Pe cin, Mi rigs dpe skrun khang), pp. 898-934.

\section{Phan bde'i bang mdzod}

Mi pham rgya mtsho 2006 gSo ba rig pa'i man ngag gces btus dang lag len dmar khrid kyi skor phan bde'i bang mdzod [Selected medical instructions, on practical advice and a treasury of happiness and well-being], in Mi pham rgya mtsho, 'Ju mi pham gyi sman yig gces bsdus [A precious cllection of Ju Mipam' medical writings] (Pe cin, Mi rigs dpe skrun khang), pp. 62-319.

\section{Phan bde'i sgo 'byed lde mig}

Karma nges don bstan 'dzin 'phrin las rab rgyas 2008 'Dod 'byung man ngag yon tan nor bu'i bang mdzod gsal byed phan bde'i sgo 'byed lde mig [An explanation of the "A treasury of wishfulfilling jewels of instructions". A key to unlock the gate to happiness and well-being], in Karma nges don bstan 'dzin 'phrin las rab rgyas, Karma ratna'i sman yig gces btus [The precious collection of Karma Ratna's medical writings] (Pe cin, Mi rigs dpe skrun khang), pp. 177-398.

\section{Phan bde'i snying po}

Tshe dbang brtan pa 2008 gSo ba rig pa'i man ngag kun gyi gces bsdus phan bde'i snying po [A selected essence of all medical instructions. The essence of happiness and well-being], in 'Bri gung Chos grags et al., 'Bri gung sman rtsis phyogs bsgrigs [A compilation of the medical and astrological writings of the 'Bri gung school] (Pe cin, Mi rigs dpe skrun khang), pp. 196-257.

\section{rGyud bzhi}

Yon tan mgon po 1982 Bdud rtsi snying po yan lag brgyad pa gsang ba man ngag gi rgyud [The essence of ambrosia. The tantras of secret instructions on the eight branches] (Lha sa, Bod ljongs mi dmangs dpe skrun khang).

\section{rGyud bzhi'i rtsa 'grel}

rNam rgyal grags pa 2008 Bdud rtsi snying po yan lag brgyad pa gsang ba man ngag gi rgyud bzhi'i rtsa ba'i 'grel ba legs pa bzhugs pa'i dbu phyogs lags so [An initial work entitled A commentary on the fundamental tantra of the "Essence of ambrosia. The tantras of secret instructions on the eight branches"], in rNam rgyal grags pa bzang po, rGyud bzhi'i rtsa ba'i 'grel pa [The commentary on the fundamental tantra of the four tantras] (Pe cin, Mi rigs dpe skrun khang), pp. 4-188.

\section{rGyud chung}

Yon tan mgon po 1999 rGyud chung bdud rtsi snying po [The minor tantra. The essence of 
ambrosia], in Yon tan mgon po et al., Cha lag bco brgyad [The eighteen additional practices], vol. 2 (Lan kru'u, Kan su'u mi rigs dpe skrun khang), pp. 755-1028.

\section{Shel gong shel phreng}

bsTan 'dzin phun tshogs 2005 Bdud rtsi sman gyi rnam dbye nus ming rgyas par bshad pa shel gong shel phreng [An extensive explanation of the classification, names and healing potential of ambrosial materia medica. A lump of crystal. A rosary of crystal] (Pe cin, Mi rigs dpe skrun khang).

\section{Si tu sMan ngo gsal byed}

Chos kyi 'byung gnas 1986 Nus pa rkyang sel gyi sman ngo gsal byed [An explanation on the identification of medicinal herbs with a healing potential to cure alone] (Leh, Tashigang).

\section{sKyem pa Tshe dbang 'Grel pa}

sKyem pa Tshe dbang 1997 rGyud bzhi'i 'grel pa [Commentary on the four tantras] (Dharamsala, Bod gzhung sman rtsis khang).

\section{Vaidūrya sngon po}

Sangs rgyas rgya mtsho 1982 gSo ba rig pa'i bstan bcos sman bla'i dgongs rgyan rgyud bzhi'i gsal byed bai Dur sngon po'i ma lli ka [A medical treatise. An adornment of medicine buddha's mind. An exposition of the four tantras. A garland of blue beryl.] (Lha sa, Bod ljongs mi dmangs dpe skrun khang).

\section{Yid bzhin nor bu}

rNam rgyal grags pa 2004 Yan lag brgyad pa'i snying po btus pa yid bzhin nor bu [The Așțāngahṛdayasaṃitā. A wish-fulfilling jewel] (Pe cin, Mi rigs dpe skrun khang).

\section{Zhal shes snying gi khu ba}

dPon tshang Ye shes 2008 Zhal shes snying gi khu ba bdud rtsi'i thigs pa'am gces btus phan bde'i snying po'i gab pa mngon du phyung ba'i lde mig [The quintessence of oral advice. Drops of ambrosia or a key to open up the hidden essence of happiness and well-being], in 'Bri gung Chos grags et al., 'Bri gung sman rtsis phyogs bsgrigs [A compilation of the medical and astrological writings of the 'Bri gung school] (Pe cin, Mi rigs dpe skrun khang), pp. 369-388.

\section{Zin thig yang thig}

Dar ma mgon po 2006 Gtsang stod zin thig dang yang thig [The concise outlines and abridged outlines of Tsangtö] (Pe cin, Mi rigs dpe skrun khang).

\section{Zin tig mdzes rgyan}

O rgyan Theg mchog 2005 Zin tig mdzes rgyan bdud rtsi'i sman mdzod [A beautiful ornament for the concise outlines. A treasury of ambrosial medicine], in Kong sprul Yon tan rgya mtsho et al., gSo rig zin tig yang tig [The medical concise outlines and abridged outlines] (Pe cin, Mi rigs dpe skrun khang), pp. 125-292.

\section{Secondary literature}

Akasoy, A. \& R. Yoeli-Tlalim 2007 Along the musk routes. Exchanges between Tibet and the Islamic World, Asian Medicine 3, pp. 217-240.

Alves, R. R. N. \& I. L. Rosa 2005 Why study the use of animal products in traditional medicines? Journal of Ethnobiology and Ethnomedicine 1(5) [online, URL : https://www.ncbi.nlm.nih.gov/pmc/ articles/PMC1277085/, accessed 22 February 2019].

Alves, R. R. N., M. F. T. Medeiros, U. P. Albuquerque \& I. L. Rosa 2014 From past to present. Medicinal animals in a historical perspective, in R. R. N. Alves \& I. L. Rosa (eds), Animals in Traditional Folk Medicine. Implications for Conservation (Berlin, Springer Berlin), pp. 11-23. 
Bao, H. 包哈申 2010 Zhan bu la dao er ji yu “mengyao zhengdian" caoben lei yaowu de yanjiu 占 布拉道尔吉与《蒙药正典》草本类药物的研究 [A study of 'Jam dpal rdo rje and medicinal herbs in the Mdzes mtshar mig rgyan], Journal of Traditional Chinese Medical Literature 中医文献杂志 1, pp. 24-26.

Bao, Y. 宝音图, B. Zhao 赵百岁 \& L. Bao 包龙 2004 Zhùmíng méng yàoxué jiā zhàn bù lā dào ěr jí shēngpíng xīn kăo 著名蒙药学家占布拉道尔吉生平新考 [A new study on the life of Mongolian physician Zhanbra Dorje], 中华医史杂志 China Journal of Medical History 34(3), pp. 162-165.

Bayartogtokh, B., U. Aibek, S. Yamane \& M. Pfeiffer 2014 Diversity and biogeography of ants in Mongolia (Hymenoptera: Formicidae), Asian Myrmecology 6, pp. 63-82.

Beckwith, C.1980 Tibetan treacle. A note on theriac in Tibet, Tibet Society Bulletin 15, pp. 49-51.

Berling, N. 2008 Heilpflanzen in der tibetischen Medizin. 61 ausgewählte Pflanzenmonographien (Essen, KVC-Verl.).

Bharti, H. 2008 Altitudinal diversity of ants in Himalayan regions (Hymenoptera: Formicidae), Sociobiology 52(2), pp. 305-322.

Bod ljongs sman rtsis khang gso rig zhib 'jug khang (ed.) 2007 Krung hva sngo 'bum bod lugs sman rdzas [Compendium of China's materia medica. Tibetan medicinal substances] (Pe cin, Krung go'i bod rig pa dpe skrun khang).

Bod rang skyong ljongs sman rtis khang (ed.) 2005 Bod sman sbyor sde chen mo [The great book on Tibetan medicinal compounds] (Lha sa, Bod ljongs mi dmangs dpe skrun khang).

Cakrapanidatta 1999 The Compendium of Ayurvedic Medicine. Principles and Practice. Being an English Translation of Cikitsāsamgraha of Cakradatta, text and English translation by a board of scholars (Delhi, Sri Satguru Publ.).

Chen, J. \& Y. Yong 陈家辉, 杨勇 2010 Qiangtang caoyuan zhiwu shibie shouce 姜塘草原植物识别手 册 [A field guide for the plants of the grassland in Northern Plateau [Byang thang]] (Kunming, Yunnan keji chubanshe).

Clark, B. 1995 The Quintessence Tantras of Tibetan Medicine (New York, Ithaca, Snow Lion Publ.)

Costa-Neto, E. M. 2005 Entomotherapy, or the medicinal use of insects, Journal of Ethnobiology 25(1), pp. 93-114.

Das, P. R. \& R. E. Emmerick (eds) 1998a Vāgbhața's Aștāangahrdayasaṃhitā. The Romanised Text Accompanied by Line and Word Indexes (Groningen, Forsten).

(eds) 1998b Vagbhata: Astangahrdayasutra. A machine-readable transcription of the Aștāngahṛdaya by Vāgbhața [online, URL : http://www.sub.unigoettingen.de/ebene_1/fiindolo/gretil/1_sanskr/ 6_sastra/7_ayur/vagaah_u.htm, accessed 4 May 2008].

Dash, V. B. 1994-2001 Encyclopaedia of Tibetan Medicine. Being the Tibetan Text of rGyud bzhi and Sanskrit Restoration of Amṛta Hṛdaya Așțānga Guhyopadeśa Tantra and Expository Translation in English (Delhi, Sri Satguru Publications).

Dašiev, D. B. 2001 Čžud-ši. Kanon tibetskoj mediciny (Moskva, Isdatel'skaja Firma “Vostočnaja Literatura" RAN).

The International Dunhuang Project: The Silk Road Online [online, URL: http://idp.bl.uk/, accessed 25 February 2019], TibHT 1, TibHT 24, TibHT 25, TibHT 26.

Dave, K. N. [1985] 2005 Birds in Sanskrit Literature, revised edition (Delhi, Motilal Banarsidass).

Dawa 1999 A Clear Mirror of Tibetan Medicinal Plants (Rome, Tibet Domani). 
Desi Sangyé Gyatso 2010 Mirror of Beryl. A Historical Introduction to Tibetan Medical Science, transl. by Gavin Kilty (Boston, Wisdom Publications).

dGa' ba'i rdo rje 1995 'Khrungs dpe dri med shel gyi me long [Sample book of materia medica. A mirror of stainless crystal] (Pe cin, Mi rigs dpe skrun khang).

dGra 'dul (ed.) 2009 Bod sman srog chags rig pa [Basic knowledge on animals in Tibetan medicine] (Lha sa, Bod ljongs mi dmangs dpe skrun khang).

Ding, Z., Y. Zhao \& X. Gao 1997 Medicinal insects in China, Ecology of Food and Nutrition 36(2-4), pp. 209-220.

Dlussky, G. M. 1965 Ants of the genus Formica L. of Mongolia and northeast Tibet (Hymenoptera, Formicidae), Annales Zoologici 23, pp. 15-43.

Eidmann, H. 1941 Zur Ökologie und Zoogeographie der Ameisenfauna von Westchina und Tibet. Wissenschaftliche Ergebnisse der 2. Brooke Dolan-Expedition 1934-1935, Zoomorphology 38, pp. 1-43.

Feng, Y., M. Zhao, Zh. He, Zh. Chen \& L. Sun 2009 Research and utilization of medicinal insects in China, Entomological Research 39, pp. 313-316.

Francke, A. H. 1924a Tibetische Handschriftenfunde aus Turfan, Sitzungsberichte der Preußischen Akademie der Wissenschaften, Philosophisch-Historische Klasse, pp. 5-20.

1924b Weitere tibetische Handschriftenfunde aus Turfan, Sitzungsberichte der Preußischen Akademie der Wissenschaften, Philosophisch-Historische Klasse, pp. 110-118.

1925 Übersetzung eines Briefes aus Turfan, wahrscheinlich aus dem 8. Jahrhundert, der von einem Krankheitsfall berichtet, Archiv für Geschichte der Medizin 17, pp. 198-199.

Germano, D. \& N. Tournadre 2003 THL Simplified Phonetic Transcription of Standard Tibetan [online, URL: http://www.thlib.org/reference/transliteration/\#!essay=/thl/phonetics/s/b2, accessed 10 July 2017].

Guo, C. \& W. Zhang 郭成, 张文波 2011 Woguo yao yong mayi de kaifa yu liyong gaikuang 我国 药用蚂蚁的开发与利用概况 [Development and utilization of medicinal ant in China], 赤峰学院 学报 (自然科学版) Journal of Chifeng University (Natural Science Edition) 27(7), pp. 22-24.

He, Y. \& J. Li 何 颖, 李经才 2003 Mayi zhiji yaoli yanjiu de xin jinzhan 蚂蚁制剂药理研究的新进 展 [New advances in pharmacology of ants], 时珍国医国药 Lishizhen Medicine and Materia Medica Research 14(2), pp. 113-115.

Hofer, T. 2014 Illustrated materia medica prints. Manuscripts and modern books, in T. Hofer, Bodies in Balance. The Art of Tibetan Medicine (New York/Seattle, Rubin Museum of Art and University of Washington Press), pp. 226-245.

Hübotter, F. 1928 Zwei tibetische Textfragmente medizinischen Inhalts aus Turfan, in E. Berghoff et al. (ed.) Internationale Beiträge zur Geschichte der Medizin. Festschrift zur Feier seines 60. Geburtstages am 8. Dezember 1928 Max Neuburger (Wien, Verlag des Fest-Komitees), pp. 188-191.

Institute of Traditional Medicine Services, Health Dept., Ministry of Health \& Education (ed.) 1999 sMan ljongs rab mdzes sngo ldum sman gyi 'khrungs dpe baidurya'i phreng ba. Medicinal Flora of Bhutan (Thimphu, Institute of Traditional Medicine Services, Health Dept., Ministry of Health \& Education).

Kala, C. P. 2003 Medicinal Plants of the Indian Trans-Himalaya. (Focus on Tibetan Use of Medicinal Resources) (Dehra Dun, Bishen Singh Mahendra Pal Singh). 
Karma chos 'phel 1993 Bdud rtsi sman gyi 'khrungs dpe legs bshad nor bu'i phreng mdzes [Sample book of materia medica of ambrosial medicine. A beautiful jewel necklace of good explanations] (Lha sa, Bod ljongs mi dmangs dpe skrun khang).

Kletter, C. \& M. Kriechbaum (eds) 2001 Tibetan Medicinal Plants (Stuttgart, Medpharm Scientific Publ.).

Le 'dod mos. Li duo mei 李多美 2009 Bod kyi gso rig tshig mdzod rab gsal me long [Dictionary of Tibetan medicine. A brilliant ceary mirror]. 简明藏医词典 [A concise dictionary of Tibetan medicine] (Pe cin, Mi rigs dpe skrun khang).

Li, J., L. Huang, M. Chen \& S. Tang 李军德, 黄路其, 陈敏, 唐仕欢 2010 Zhongyao meng chong yanjiu jinzhan 中药虬虫研究进展 [Progress on the study of Gadfly in Chinese medicine], 中国实 验方剂学杂志 Chinese Journal of Experimental Traditional Medical Formulae 16(8), pp. 228-230.

Lokesh Chandra (ed.) 1971 An Illustrated Tibeto-Mongolian Materia Medica of Ayurveda of 'Jam-dpalrdo-rje of Mongolia (New Delhi, International Academy of Indian Culture).

Lokeshwari, R. K. \& T. Shantibala 2010 A review on the fascinating world of insect resources. Reason for thoughts, Psyche, article 207570, pp. 1-11 [online, URL: http://dx.doi.org/ $10.1155 / 2010 / 207570]$

Luo, B. 罗秉芬 Lu'o ping hphen (ed.) 2002 敦煌本吐蕃医学文献精要Tun hong nas thon pa'i bod kyi gso rig yig cha gces bsdus [A precious collection of medical manuscripts from Dunhuang] (Pe cin, Mi rigs dpe skrun khang).

Luo, D. 罗达尚 1997 Zhonghua zang bencao 中华藏本草 [Materia medica of China’s Tibetan medicine] (Beijing, Minzu chubanshe).

Mahawar, M. M. \& D. P. Jaroli 2008 Traditional zootherapeutic studies in India. A review, Journal of Ethnobiology and Ethnomedicine 4(17), pp. 1-12 [online, URL: http://

ethnobiomed.biomedcentral.com/articles/10.1186/1746-4269-4-17, accessed 22 February 2019].

Mahulikar, G. (ed.) 2016 Animals and Birds in Sanskrit Literature (Delhi, New Bharatiya Book Corporation).

Mans, D. R. A, S. Sairras, D. Ganga \& J. Kartopawiro 2016 Exploring the global animal biodiversity in the search for new drugs - insects, Journal of Translational Science 3(1), pp. 371-386.

Meyer-Rochow, V. B. \& J. Chakravorty 2013 Notes on entomophagy and entomotherapy generally and information on the situation in India in particular, Applied Entomology and Zoology 48(2), pp. 105-112.

Mo, G. 莫国香 \& S. Wang 王思明 2013 Niumeng zuowei zhongyao yaocai de ren zhi ji qi liyong 牛 虬作为中药药材的认知及其利用 [Functional identification and application of horsefly as a representative form of traditional Chinese medicine], 动物学研究 Zoological Research 34(6), pp. 694-699.

Moed, L., T. A. Shwayder \& C. Wu 2001 Cantharidin revisited. A blistering defense of an ancient medicine, Archives of Dermatology 137(10), pp. 1357-1360.

Namba, T., Y. H. Ma \& K. Inagaki 1988 Insect-derived crude drugs in the Chinese Song dynasty, Journal of Ethnopharmacology 24(2-3), pp. 247-285.

Narsu \& K. Stuart 1988 Insects used in Mongolian medicine, Journal of the Anglo-Mongolian Society 11(1), pp. 7-13.

Noack, T. 1903 Zur Entwicklung von Equus przewalskii, Zoologischer Anzeiger 26, pp. 370-373. 
Olivelle, P. [2002] 2011 Food for thought. Dietary rules and social organization in Ancient India, in P. Olivelle, Language, Texts, and Society. Explorations in Ancient Indian Culture and Religion (London, Anthem Press), pp. 367-394.

Parfionovitch, Y., F. Meyer \& Gyurme Dorje (eds) 1992 Tibetan Medical Paintings. Illustrations to the Blue Beryl Treatise of Sangye Gyamtso (1653-1705) (London, Serindia Publications).

Pa sangs yon tan 1994 Bod kyi sman rdzas rig pa'i tshig mdzod g.yu thog sngo 'bum dgongs rgyan [A basic dictionary of Tibetan materia medica. An adornment of thoughts to Yutok's 'Collection of medicinal plants'] (Milano, Lama Gangchen World Peace Foundation).

Pasang Yonten Arya 1998 Dictionary of Tibetan Materia Medica (Delhi, Motilal Banarsidass Publ.).

Pfeiffer, M., R. Schultz, A. Radchenko, S. Yamane, M. Woyciechowski, A. Ulykpan \& B. Seifert 2006 A critical checklist of the ants of Mongolia (Hymenoptera: Formicidae), Bonner zoologische Beiträge 55(1), pp. 1-8.

rNam rgyal thar (ed.) 2006 Bod sman srog chags rig pa [Basic knowledge on animals in Tibetan medicine] (Pe cin, Mi rigs dpe skrun khang).

Sabernig, K. 2011 The substitution of rare ingredients in traditional Tibetan medicine on the basis of classical Tibetan texts, their use in modern formularies and a case study from Amdo/Qinghai, Curare 34(1-2). pp. 83-96.

Semichov, B. V. (ed.) 1981 Glang thabs (acute diseases of the organs of the abdominal cavity) and their correction in Tibetan medicine, Tibetan Medicine (Dharamsala) 4.

Shrivastava, S. K. \& A. Prakash 2015 Entomotherapy. An un-explored frontier for make in India. A Review, Journal of Applied Zoological Researches 26(2), pp. 113-123.

Srikantha Murthy, K. R. [1992-1997] 2004-2005 Vāgbhața's Așțāña hrdayam. (Text, English Translation, Notes, Appendix and Indices) (Varanasi, Krishnadas Academy).

Still, J. 2003 Use of animal products in traditional Chinese medicine. Environmental impact and health hazards, Complementary Therapies in Medicine 11, pp. 118-122.

Taube, M. 1980 Die Tibetica der Berliner Turfansammlung (Berlin, Akademie Verlag).

Tenzin Dakpa 2007 Tibetan Medicinal Plants. An Illustrated Guide to Identification and Practical Use (New Delhi, Paljor Publ).

Thapa, V. K. 2000 An Inventory of Nepal's Insects. Volume III (Hemiptera, Hymenoptera, Coleoptera \& Diptera) (Kathmandu, IUCN Nepal).

The Plant List 2013 Version 1.1. [online, URL: http://www.theplantlist.org/, accessed 14 September 2016].

Thinley Gyatso C. Hakim 2010 Essentials of Tibetan Traditional Medicine (Berkeley, Calif., North Atlantic Books).

Tsering Dorjee Dekhang 2008 A Handbook of Tibetan Medicinal Plants, $3^{\text {rd }}$ edition (Dharamsala, Tibetan Medical \& Astrological Institut).

Tian, S. 田淑琴 1997 Changyong zangyao zhi 常用藏药志 [Manual of common Tibetan materia medica] (Chengdu, Sichuan kexue jizhu chubanshe).

Tsarong, T. J. 1994 Tibetan Medicinal Plants (Kalimpong, Tibetan Medical Publ).

Unnikrishnan, P. M. 1998 Animals in Ayurveda, Amruth 1(3), pp. 1-23. 
Van Schaik, S. 2013 Ruler of the East, or eastern capital. What lies behind the name Tong kun?, in I. Galambos (ed.), Studies in Chinese Manuscripts. From the Warring States to the Twentieth Century (Budapest, Eötvös Loránd University), pp. 211-223.

Van Schaik, S. \& I. Galambos 2012 Manuscripts and Travellers. The Sino-Tibetan Documents of a Tenthcentury Buddhist Pilgrim (Berlin, de Gruyter).

Verma, A. K. \& S. B. Prasad 2012 Bioactive component, cantharidin from Mylabris cichorii and its antitumor activity against Ehrlich ascites carcinoma, Cell Biology and Toxicology 28(3), pp. 133-147.

Wang, B., W. Yuan, C. Wang, F. Huang, D. Lin \& Z. Tang 王保海, 袁维红, 王成明, 黄复生, 林大武, 唐昭华 1992 Xizang kunchong qu xi ji qi yanhua 西藏昆虫区系及其演化 The Xizang insect fauna and its evolution (Kaifeng, Henan Science and Technology Publ. House).

Wujastyk, D. 2003 The Roots of Ayurveda. Selections from Sanskrit Medical Writings (London, Penguin Books).

Yi, C., Q. He, L. Wang \& R. Kuang 2010 The utilization of insect-resources in Chinese rural area, Journal of Agricultural Science 2(3), pp. 146-154.

Yoeli-Tlalim, R. 2013 Central Asian mélange. Early Tibetan medicine from Dunhuang, in B. Dotson, I. Kazushi \& T. Takeuchi (eds), Scribes, Texts, and Rituals in Early Tibet and Dunhuang (Wiesbaden, Reichert Verlag), pp. 53-60.

2015 Between medicine and ritual. Tibetan "medical rituals" from Dunhuang, in C. Ramble \& U. Roesler (eds), Tibetan and Himalayan Healing. An Anthology for Anthony Aris (Kathmandu, Vajra Publications), pp. 749-755.

Yonten Gonpo, Y. 2011a The Root Tantra and the Explanatory Tantra from the Secret Quintessential Instructions on the Eight Branches of the Ambrosia Essence Tantra From the Four Tantras of Tibetan Medicine, translated into English by Translation Department, Men-Tsee-Khang, Dharamsala, $2^{\text {nd }}$ edition (Dharamsala, Men-Tsee-Khang Publ.).

2011 b Bod kyi gso ba rig pa'i rgyud bzhi las phyi ma rgyud. The Subsequent Tantra. From the Four Tantras of Tibetan Medicine, translated into English by Translation Department, Men-Tsee-Khang, Dharamsala, $2^{\text {nd }}$ edition (Dharamsala, Men-Tsee-Khang).

Zhang, C., X. Tang \& J. Cheng 2008 The utilization and industrialization of insect resources in China, Entomological Research 38(1), pp. 38-47.

Zhang, L. \& J. Guo 张笠, 郭建军 2011 Jiu xiang chong ziyuan ji qi liyong yanjiu 九香虫资源及其 利用研究 [Study on the resources and utilization of Aspongopus chinensis Dallas), 西南师范大学学 报(自然科学版) Journal of Southwest China Normal University (Natural Science Edition) 36(5), pp. 151-155.

Zhang, S. \& H. Liu 张莎, 刘华一 2014 Liu hua yi miaoyong jiu xiang chong zhiliao weitong jingyan 刘华一妙用九香虫治疗胃痛经验 [Liu Huayi's experience. Wonderful use of Aspongopus chinensis Dallas for treatment of stomach pain], 北京中医药 Beijing Chinese Medicine 33(3), pp. 182-183.

Zhongguo kexue yuan xibei gaoyuan shengwu yanjiusuo 中国科学院西北高原生物研究所 [Northwest Institute of Plateau Biology, Chinese Academy of Sciences] (ed.) 1991 Zangyao zhi 藏药 志 [Manual of Tibetan materia medica] (Xining, Qinghai ren min chu ban she).

Zimmermann, F. [1982] 1999 The Jungle and the Aroma of Meats. An Ecological Theme in Hindu Medicine (Delhi, Motilal Banarsidass). 


\section{APPENDIXES}

\section{chagapa (cha ga pa)}

All authors agree that is a kind of grasshopper but disagree which it is exactly. A few prefer the Oxya chinensis Thunberg. Most identify it as Patanga japonica Bolivar. In the opinion of Luo 1997, one has to distingusih between a common grasshopper (cha ga pa) and the grasshopper of the valleys (rong cha ga pa). The former is the Patanga japonica and the latter a cicada.

\begin{tabular}{|l|l|l|}
\hline (i) & Oxya chinensis Thunberg & $\begin{array}{l}\text { Dga' ba'i rdo rje 1995, p. 374; } \\
\text { Pasang Yonten Arya 1998, p. 63; }\end{array}$ \\
\hline (ii) & Patanga japonica Bolivar & $\begin{array}{l}\text { Zhongguo kexue yuan xibei gaoyuan shengwu } \\
\text { yanjiusuo 1991, p. 491; } \\
\text { Parfionovitch et al. 1992, p. 233; } \\
\text { Karma chos 'phel 1993, p. 698; } \\
\text { Qinghaisheng yaopin jianyan suo 1996, vol. 3, p. 93; } \\
\text { Rnam rgyal thar 2006, p. 205; } \\
\text { Dgra 'dul 2009, p. 239; }\end{array}$ \\
\hline (iii) & $\begin{array}{l}\text { 1. Patanga japonica (Bolivar) (cha ga pa) } \\
\text { cha ga pa) }\end{array}$ & \begin{tabular}{l} 
Luo 1997, p. 300. \\
\hline
\end{tabular} \\
\hline
\end{tabular}

\section{chubur (chu sbur)}

One scholar gives the family of water beetles. Others are more specific and identify it as Cybister tripunctatus orientalis Gschwendtner which is a synonym for Cybister tripunctatus lateralis Fabricius.

\begin{tabular}{|l|l|l|}
\hline (i) & Dytiscidae & Parfionovitch et al. 1992, p. 227; \\
\hline (ii) & Cybister tripunctatus orientalis Gschwendtner & $\begin{array}{l}\text { Dga' ba'i rdo rje 1995, p. 374; } \\
\text { Pasang Yonten Arya 1998, p. 66; } \\
\text { Rnam rgyal thar 2006, p. 219. }\end{array}$ \\
\hline
\end{tabular}

\section{gowo (go bo)}

All scholars are in agreement that the bird called gowo is the Gypaetus barbatus (hemachalanus) Hutton, $p$. 


\begin{tabular}{|c|c|c|c|}
\hline (i) & $\begin{array}{l}\text { Gypaetus barbatus } \\
\text { Hutton }\end{array}$ & (hemachalanus) & $\begin{array}{l}\text { Zhongguo kexue yuan xibei gaoyuan shengwu yanjiusuo } \\
\text { 1991, p. 479; } \\
\text { Parfionovitch et al. 1992, p. 233; } \\
\text { Karma chos 'phel 1993, p. 656; } \\
\text { Dga' ba'i rdo rje 1995, p. 361; } \\
\text { Qinghaisheng yaopin jianyan suo 1996, vol. } 3 \text { p. 52; } \\
\text { Luo 1997, p. 313; } \\
\text { Pasang Yonten Arya 1998, p. 35; } \\
\text { Bod ljongs sman rtsis khang gso rig zhib 'jug khang } \\
\text { 2007, p. 831; } \\
\text { Dgra 'dul 2009, p. 194; } \\
\text { Rnam rgyal thar 2006, p. } 164 \text {. }\end{array}$ \\
\hline
\end{tabular}

\section{gyakyek (rgya skyegs)}

There is a generel consensus that gyakyek is the lac insect or the lac itself. It seems that a few authors regard the term as pointing out to the host plant.

\begin{tabular}{|c|c|c|}
\hline (i) & Laccifer lacca Kerr & $\begin{array}{l}\text { Xizang deng weishengju 1979, p. 83; } \\
\text { Yang Jingsheng and Chucheng jiangcuo 1987, p. 59; } \\
\text { Zhongguo kexue yuan xibei gaoyuan shengwu yanjiusuo 1991, } \\
\text { p. } 60 \text {; } \\
\text { Karma chos 'phel 1993, p. 129; } \\
\text { Dga' ba'i rdo rje 1995, p. 123; } \\
\text { Qinghaisheng yaopin jianyan suo 1996, vol. } 2 \text { p. 50; }\end{array}$ \\
\hline (ii) & red lac & Pasang Yonten Arya 1998, p. 43; \\
\hline (iii) & $\begin{array}{l}\text { shellac, derived from Ficus } \\
\text { sp. }\end{array}$ & Parfionovitch et al. 1992, pp. 81, 237; \\
\hline (iv) & gyakyek tree & Clark 1995, p. 169; \\
\hline (v) & $\begin{array}{l}\text { 1. shellac } \\
\text { 2. Laccifer lacca }\end{array}$ & Thinley Gyatso and Hakim 2010, p. 166; \\
\hline (vi) & $\begin{array}{l}\text { 1. Laccifer lacca Kerr } \\
\text { 2. Eriolaena spp. }\end{array}$ & Luo 1997, p. 301. \\
\hline
\end{tabular}

\section{jagö (bya rgod)}

Modern scholars agree that the jagö is the cinereous vulture. Two authors just state that the jagö is a (Himalayan) vulture. 


\begin{tabular}{|l|l|l|}
\hline \multirow{2}{*}{ (i) } & $\begin{array}{l}\text { Aegypius } \\
\text { (Linnaeus) }\end{array}$ & $\begin{array}{l}\text { Zhongguo kexue yuan xibei gaoyuan shengwu yanjiusuo 1991, } \\
\text { p. 518; } \\
\text { Karma chos 'phel 1993, p. 654; } \\
\text { Dga' ba'i rdo rje 1995, p. 367; } \\
\text { Qinghaisheng yaopin jianyan suo 1996, vol. 2, p. 142; } \\
\text { Luo 1997, p. 312; } \\
\text { Bod ljongs sman rtsis khang gso rig zhib 'jug khang 2007, p. 812; } \\
\text { Dga 'dul 2009, p. 191; } \\
\text { Rnam rgyal thar 2006, p. 161; }\end{array}$ \\
\hline (ii) & Himalayan vulture & $\begin{array}{l}\text { Parfionovitch et al. 1992, p. 67, 213, 233, 243; } \\
\text { Pasang Yonten Arya 1998, p. 155). }\end{array}$ \\
\hline
\end{tabular}

\section{jangpa (byang pa)}

Modern authors disagree about which species jangpa refers. Some are of the opinion that jangpa is Mylabris phalerata Pallas, but others identify it with Mylabris cichorii Fabricius. Two scholars give both species. Furthermore, the author of one publication prefer not to specify it further, $p$.

\begin{tabular}{|c|c|c|}
\hline (i) & Mylabris sp. & Parfionovitch et al. 1992, p. 71, 227, 273; \\
\hline (ii) & Mylabris phalerata Pallas & $\begin{array}{l}\text { Xizang deng weishengju 1979, p. 79; } \\
\text { Yang Jingsheng and Chucheng jiangcuo 1987, p. 79; } \\
\text { Dga' ba'i rdo rje 1995, p. 379; } \\
\text { Qinghaisheng yaopin jianyan suo 1996, vol. 2, p. 147; } \\
\text { Pasang Yonten Arya 1998, p. 158; }\end{array}$ \\
\hline (iii) & Mylabris cichorii Fabricius & $\begin{array}{l}\text { Zhongguo kexue yuan xibei gaoyuan shengwu yanjiusuo } 1991 \text {, } \\
\text { p. 519; } \\
\text { Karma chos 'phel 1993, p. } 696 \text {; } \\
\text { Bod ljongs sman rtsis khang gso rig zhib 'jug khang 2007, p. 855; } \\
\text { Dgra 'dul 2009, p. 237; } \\
\text { Rnam rgyal thar 2006, p. 203; }\end{array}$ \\
\hline (iv) & $\begin{array}{l}\text { 1. Mylabris phalerata Pallas, } \\
\text { 2. Mylabris cichorii } \\
\text { Fabricius }\end{array}$ & $\begin{array}{l}\text { Clark 1995, p. 182; } \\
\text { Luo 1997, p. } 303 .\end{array}$ \\
\hline
\end{tabular}

\section{jelep sertra (bye leb ser khra)}

The term jelep sertra can be rendered as yellow mottled butterfly. There exist other Tibetan terms for butterfly as well such as chemalep (phye ma leb), which can also denote a moth. Occassionally one also finds the term jetak (bye stag) which can be used as a synonym for both terms. Some Western authors writes that it might mean any 
butterfly. Other are more specific and identify it as the common yellow swallowtail, the eastern pale clouded yellow, or the high-altitude butterfly Parnassius imperator. One author provides two identifications.

\begin{tabular}{|c|c|c|}
\hline (i) & butterfly / Lepidoptera & $\begin{array}{l}\text { Pasang Yonten Arya 1998, p. } 162 \text { (phye ma leb); } \\
\text { Dašieva 2001, p. } 726 \text { (bye stag); }\end{array}$ \\
\hline (ii) & Papilio machaon L. & $\begin{array}{l}\text { Dga' ba'i rdo rje 1995, p. } 380 \text { (bye leb ser khra); } \\
\text { Dgra 'dul 2009, p. } 240 \text { (phye ma leb); }\end{array}$ \\
\hline (iii) & Colias erate Esper & $\begin{array}{l}\text { Qinghaisheng yaopin jianyan suo 1996, p. vol. } 3221 \\
\text { (bye ma leb ser khra); }\end{array}$ \\
\hline (iv) & $\begin{array}{l}\text { Parnassius imperator musageta Grum- } \\
\text { Grshimailo }\end{array}$ & $\begin{array}{l}\text { Zhongguo kexue yuan xibei gaoyuan shengwu } \\
\text { yanjiusuo 1991, p. } 521 \text { (bye stag khra bo); } \\
\text { Karma chos 'phel 1993, p. } 701 \text { (phye ma leb); } \\
\text { Parfionovitch et al. } 1992, \text { p. } 235 \text { (bye stag); } \\
\text { Rnam rgyal thar 2006, p. } 206 \text { (bye leb ser khra); }\end{array}$ \\
\hline (v) & $\begin{array}{l}\text { 1. Colias erate Esper (bye leb ser khra) } \\
\text { 2. Parnassius imperator musageta Grum- } \\
\text { Grshimailo (bye stag khra bo) }\end{array}$ & Luo 1997, p. 302. \\
\hline
\end{tabular}

\section{jingjingtulu (bying bying thu lu)}

The opinions vary with regard to its identification. Some think it is the dung beetle Scarabaeus sacer, whereas others state that it is the stink bug (Aspongopus chinensis Dallas is a synonym for Coridius chinensis Dallas). Several scholars, however, prefer the identification of a wingless cockroach.

One author gives two identification but without specifying it further.

\begin{tabular}{|l|l|l|}
\hline (i) & Scarabaeus sacer & $\begin{array}{l}\text { Parfionovitch et al. 1992, p. 227; } \\
\text { Dašieva 2001, p. 88, 327; }\end{array}$ \\
\hline (ii) & Aspongopus chinensis Dallas & $\begin{array}{l}\text { Karma chos 'phel 1993, p. 696; } \\
\text { Rnam rgyal thar 2006, p. 202; }\end{array}$ \\
\hline (iii) & $\begin{array}{l}\text { Eupolyphaga } \\
\text { Walker }\end{array}$ & $\begin{array}{l}\text { Zhongguo kexue yuan xibei gaoyuan shengwu yanjiusuo 1991, } \\
\text { p. 520; } \\
\text { Dga' ba'i rdo rje 1995, p. 379; } \\
\text { Qinghaisheng yaopin jianyan suo 1996, vol. 3, p. 211; } \\
\text { Luo 1997, p. 300; } \\
\text { Pasang Yonten Arya 1998, p. 161; } \\
\text { Dgra 'dul 2009, p. 236; }\end{array}$ \\
\hline
\end{tabular}




\section{kyiwa (skyi ba)}

In the literature on Tibetan materia medica, there is an agreement that the kyiwa plant belongs to the genus Sophora. Some of the scientific names represent synonyms. Sophora moorcroftiana var. davidii Franch. and Sophora viciifolia Hance are alternative names of Sophora davidii (Franch.) Pavol.

\begin{tabular}{|l|l|l|}
\hline (i) $\begin{array}{l}\text { Sophora davidii (Franch.) } \\
\text { Pavol. }\end{array}$ & $\begin{array}{l}\text { Dga' ba'i rdo rje 1995, p. 116; } \\
\text { Pasang Yonten Arya 1998, p. 15; }\end{array}$ \\
\hline (ii) & $\begin{array}{l}\text { Sophora } \\
\text { (Benth.) Baker } \\
\text { bsten cus 1973, p. 226, pl. 116; } \\
\text { Gurmet Namgyal and Phuntsog 1990, p. 314; } \\
\text { Zhongguo kexue yuan xibei gaoyuan shengwu yanjiusuo } \\
\text { (Northwest Institute of Plateau Biology, Chinese Academy of } \\
\text { Sciences) (ed.) 1991, p. 16; } \\
\text { Parfionovitch et al. 1992, pp. 69, 81, 225, 237; } \\
\text { Karma chos 'phel 1993, p. 57; } \\
\text { Clark 1995, p. 172; } \\
\text { Qinghaisheng yaopin jianyan suo 1996, vol. 3, p. 27; } \\
\text { Luo 1997, p. 141; } \\
\text { Tian 1997, p. 160; } \\
\text { Dawa 1999, p. 314; } \\
\text { Dašieva 2001, p. 744; } \\
\text { Bod ljongs sman rtsis khang gso rig zhib 'jug khang 2007, p. 539; }\end{array}$ \\
\hline $\begin{array}{l}\text { (iii) } \\
\text { 1. Sophora davidii (Franch.) } \\
\text { 2. Sophol. } \\
\text { Benth. var. davidii Franch. } \\
\text { 3. Sophora viciifolia Hance }\end{array}$ & $\begin{array}{l}\text { Yang Jingsheng and Chucheng jiangcuo 1987, p. 127. } \\
\text { moorcroftiana }\end{array}$ \\
\hline
\end{tabular}

\section{rakshamikmé (raksha mig med)}

There is an agreement that it is an ant. Some authors consider it the common black colored ant.

\begin{tabular}{|l|l|l|}
\hline (i) & ant & Pasang Yonten Arya 1998, p. 242; \\
\hline (ii) & Formica & Parfionovitch et al. 1992, pp. 75, 231; \\
\hline
\end{tabular}




\section{sebur (bse sbur)}

There is some disagreement what sebur is. One author refers to beetles of the Blaps genus. Another states that is a species of dung beetle. Parfionovitch et al. 1992 gives a slightly confusing statement by saying that it are beetles (coleopterae) and then adds stink bugs. Indeed many scholars consider sebur to be Nezara viridula, a plant-feeding stink bug. This also applies to Luo 1997 but he also provides a further possible identification, a certain species of dung beetle. Clark 1995 differs significantly by providing three potential identifications, namely the oriental cockroach, the American cockroach or a species of dung beetle.

\begin{tabular}{|l|l|l|}
\hline (i) & Blaps spp. & Dašieva 2001, p. 88; \\
\hline (ii) & Catharsius molossus L. & $\begin{array}{l}\text { Qinghaisheng yaopin jianyan suo 1996, vol.3, } \\
\text { p. 376; }\end{array}$ \\
\hline (iii) & Coleopterae (stink bug) & Parfionovitch et al. 1992, p. 227; \\
\hline (iv) & Nezara viridula smaragdula Fabricius & $\begin{array}{l}\text { Yang Jingsheng and Chucheng jiangcuo 1987, } \\
\text { Karma chos 'phel 1993, p. 695; } \\
\text { Rnam rgyal thar 2006, p. 201; } \\
\text { Dgra 'dul 2009, p. 235; }\end{array}$ \\
\hline (v) & $\begin{array}{l}\text { 1. Catharsius molossus L. (bse sbur) } \\
\text { bo) }\end{array}$ & $\begin{array}{l}\text { 1. Blatta orientalis L. } \\
\text { 2. Periplaneta Americana } \\
\text { 3. Geotrupes laevistriatus }\end{array}$ \\
\hline
\end{tabular}

\section{sema (srad ma)}

In Tibetan medicine, there are several types depending on the color. In Western literature, the white type (sekar, srad dkar), blue-greenish type (sengön, srad sngon) and the black type (senak, srad nag) are usually regarded as a plant in the genera Astragalus and Oxytropis. The yellow type (seser, srad ser) is mainly identified as a species of the genera Astragalus and Hedysarum. The red type (semar, srad dmar) is said to beling to the genus Hedysarum. Plants of the brownish type (semuk, srad smug) are classified as plants from the genera Tibetia, Astragalus and Oxytropis. Some of desigations are synonyms. Astragalus yunnanensis var. tatsienensis (Bureau \& Franch.) Cheng $\mathrm{f}$. is a synonym of 
Astragalus tatsienensis Bureau \& Franch. The name Gueldenstaedtia himalaica Baker is a synonym of Tibetia himalaica (Baker) H.P.Tsui.

\section{(A) (sekar)}

\begin{tabular}{|c|c|c|}
\hline (i) & Astragalus sp. & $\begin{array}{l}\text { Gurmet Namgyal and Phuntsog 1990, p. } 320 \text {; } \\
\text { Dašieva, D. B. 2001, p. 726; }\end{array}$ \\
\hline (ii) & Astragalus floridus Bunge & $\begin{array}{l}\text { Dga' ba'i rdo rje 1995, p. 309; } \\
\text { Pasang Yonten Arya 1998, p. 282; }\end{array}$ \\
\hline (iii) & Astragalus yunnanensis Fr. & $\begin{array}{l}\text { Bod rang skyong ljongs gsar brje u yon lhan khang gi 'phrod } \\
\text { bsten cus 1973, p. 541, pl. 342; }\end{array}$ \\
\hline (iv) & Oxytropis sp. & Thinley Gyatso and Hakim 2010, p. 281; \\
\hline (v) & Oxytropis ochrantha Turcz. & Dawa 1999, p. 242; \\
\hline (vi) & Oxytropis kansuensis Bunge & $\begin{array}{l}\text { Bod ljongs sman rtsis khang gso rig zhib 'jug khang 2007, } \\
\text { p. 267; }\end{array}$ \\
\hline (vii) & $\begin{array}{l}\text { 1. Oxytropis kansuensis Bunge } \\
\text { 2. Oxytropis ochrocephala Bunge }\end{array}$ & $\begin{array}{l}\text { Karma chos 'phel 1993, p. 449; } \\
\text { Qinghaisheng yaopin jianyan suo 1996, vol. 1, p. 534; } \\
\text { Luo 1997, p. 138; }\end{array}$ \\
\hline (viii) & $\begin{array}{l}\text { 1. Astragalus yunnaneansis } \\
\text { 2. Oxytropis oxyphylla }\end{array}$ & Clark 1995, p. 170; \\
\hline (ix) & $\begin{array}{l}\text { 1. Astragalus acaulis Baker } \\
\text { 2. Astragalus tatsienensis } \\
\text { Bureau \& Franch. } \\
\text { 3. Oxytropis kansuensis Bunge }\end{array}$ & Yang Jingsheng and Chucheng jiangcuo 1987, p. 623; \\
\hline (x) & $\begin{array}{l}\text { 1. Astragalus galactites Pall. } \\
\text { 2. Astragalus yunnanensis } \\
\text { Franch. } \\
\text { 3. Oxytropis ochrocephala Bunge }\end{array}$ & $\begin{array}{l}\text { Zhongguo kexue yuan xibei gaoyuan shengwu yanjiusuo } \\
\text { 1991, p. 418; }\end{array}$ \\
\hline (xi) & $\begin{array}{l}\text { 1. Astragalus sp. } \\
\text { 2. Hedysarum sp. }\end{array}$ & Parfionovitch et al. 1992, pp. 69, 225. \\
\hline
\end{tabular}

\section{(B) (seser)}

\begin{tabular}{|l|l|l|}
\hline (i) & Taverniera nummularia DC. & Tsering Dorjee Dekhang 2008, p. 184; \\
\hline (ii) & Astragalus pulvinatus P.C.Li et Ni & Chen Jiahui and Yang Yong 2010, p. 84; \\
\hline (iii) & $\begin{array}{l}\text { Astragalus yunnanensis var. tatsienensis } \\
\text { (Bureau \& Franch.) Cheng f. }\end{array}$ & $\begin{array}{l}\text { Dga' ba'i rdo rje 1995, p. 310; } \\
\text { Pasang Yonten Arya 1998, p. 283; }\end{array}$ \\
\hline
\end{tabular}




\begin{tabular}{|l|l|l|}
\hline (iv) & Astragalus floridus Bunge & $\begin{array}{l}\text { Bod rang skyong ljongs gsar brje u yon lhan khang } \\
\text { gi 'phrod bsten cus 1973, p. 541, pl. 344; } \\
\text { Zhongguo kexue yuan xibei gaoyuan shengwu } \\
\text { yanjiusuo 1991, p. 422; } \\
\text { Pa sang yon tan 1994, p. 78; } \\
\text { Tsarong 1994, p. 78; } \\
\text { Karma chos 'phel 1993, p. 452; } \\
\text { Bod ljongs sman rtsis khang gso rig zhib jug } \\
\text { khang 2007, p. 269; }\end{array}$ \\
\hline (v) & $\begin{array}{l}\text { 1. Astragalus floridus Bunge } \\
\text { 2. Astragalus chrysopterus Bunge }\end{array}$ & $\begin{array}{l}\text { Luo 1997, p. 127; } \\
\text { (vi) }\end{array}$ \\
$\begin{array}{l}\text { 1. Astragalus ernestii H.F.Comber } \\
\text { 2. Hedysarum thiochroum Hand.-Mazz. } \\
\text { 3. Astragalus prattii G.Simpson }\end{array}$ & $\begin{array}{l}\text { Yang Jingsheng and Chucheng jiangcuo 1987, } \\
\text { p. 631; }\end{array}$ \\
\hline (vii) & $\begin{array}{l}\text { 1. Hedysarum polybotrys Hand.-Mazz. } \\
\text { 2. Hedysarum citrinum Baker f. }\end{array}$ & $\begin{array}{l}\text { Qinghaisheng yaopin jianyan suo 1996, vol. 1, } \\
\text { p. 539. }\end{array}$ \\
\hline
\end{tabular}

\section{(C) (sengön)}

\begin{tabular}{|c|c|c|}
\hline (i) & $\begin{array}{l}\text { Astragalus pastorius H.T.Tsai \& } \\
\text { T.F.Yu }\end{array}$ & $\begin{array}{l}\text { Dga' ba'i rdo rje 1995, p. } 309 ; \\
\text { Pasang Yonten Arya 1998, p. 282; }\end{array}$ \\
\hline (ii) & Astragalus tanguticus Batalin & Luo 1997, p. 129; \\
\hline (iii) & Oxytropis melanocalyx Bunge & $\begin{array}{l}\text { Karma chos 'phel 1993, p. 451; } \\
\text { Qinghaisheng yaopin jianyan suo 1996, p. vol. } 1536 \text {; }\end{array}$ \\
\hline (iv) & $\begin{array}{l}\text { 1. Oxytropis melanocalyx Bunge } \\
\text { 2. Astragalus skythropos Bunge } \\
\text { 3. Astragalus licentianus Hand.- } \\
\text { Mazz. }\end{array}$ & Yang Jingsheng and Chucheng jiangcuo 1987, p. 625; \\
\hline (v) & $\begin{array}{l}\text { 1. Astragalus tanguticus Batalin } \\
\text { 2. Oxytropis melanocalyx Bunge } \\
\text { 3. Hedysarum tuberosum } \\
\text { B.Fedtsch. }\end{array}$ & $\begin{array}{l}\text { Zhongguo kexue yuan xibei gaoyuan shengwu yanjiusuo } \\
\text { 1991, p. } 424 \text {. }\end{array}$ \\
\hline
\end{tabular}

\section{(D) (senak)}

\begin{tabular}{|l|l|l|}
\hline (i) & $\begin{array}{l}\text { 1. Astragalus kialensis } \\
\text { G.Simpson } \\
\text { 2. Astragalus josephi E.Peter }\end{array}$ & Yang Jingsheng and Chucheng jiangcuo 1987, p. 627; \\
\hline
\end{tabular}




\begin{tabular}{|l|l|l|}
\hline (ii) & $\begin{array}{l}\text { 1. Oxytropis coerulea (Pall.) DC. } \\
\text { 2. Astragalus bhotanensis Baker }\end{array}$ & $\begin{array}{l}\text { Zhongguo kexue yuan xibei gaoyuan shengwu yanjiusuo 1991, } \\
\text { p. 420; }\end{array}$ \\
\hline (iii) & Astragalus kialensis G.Simpson & Karma chos 'phel 1993, p. 450; \\
\hline (iv) & Oxytropis subpodoloba P.C. Li & $\begin{array}{l}\text { Dga' ba'i rdo rje 1995, p. 309; } \\
\text { Pasang Yonten Arya 1998, p. 282; }\end{array}$ \\
\hline (v) & Hedysarum sikkimense Benth. & Qinghaisheng yaopin jianyan suo 1996, vol. 1, p. 537; \\
\hline (vi) & $\begin{array}{l}\text { Simpson } \\
\text { 2. Astragalus josephi E. Peter }\end{array}$ & Luo 1997, p. 127. \\
\hline
\end{tabular}

\section{(E) (semar)}

\begin{tabular}{|l|l|l|}
\hline (i) & Hedysarum sikkimense Benth. & $\begin{array}{l}\text { Zhongguo kexue yuan xibei gaoyuan shengwu yanjiusuo } \\
1991, \mathrm{p.} \mathrm{421;}\end{array}$ \\
\hline (ii) & $\begin{array}{l}\text { B.Fedtsch. } \\
\begin{array}{l}\text { 3. Hedysarum sikkimense Baker } \\
\text { Ulbr. Hedysarum pseudastragalus }\end{array}\end{array}$ & Yang Jingsheng and Chucheng jiangcuo 1987, p. 628; \\
\hline (iii) & $\begin{array}{l}\text { Hedysarum sikkimense Baker } \\
\text { (iv) }\end{array}$ & $\begin{array}{l}\text { Kedysarum multijugum Maxim. ba'i rdo rje 1995, p. 310; } \\
\text { Pasang Yonten Arya 1998, p. 283; }\end{array}$ \\
\hline (v) & Qinghaisheng yaopin jianyan suo 1996, vol. 3, p. 368; \\
\hline
\end{tabular}

\section{(F) (semuk)}

\begin{tabular}{|l|l|l|}
\hline (i) & $\begin{array}{l}\text { 1. Gueldenstaedtia himalaica Baker } \\
\text { 2. Oxytropis yunnanensis Franch. } \\
\text { 3. Astragalus polycladus Bureau \& Franch. }\end{array}$ & $\begin{array}{l}\text { Zhongguo kexue yuan xibei gaoyuan shengwu } \\
\text { yanjiusuo 1991, p. 426; }\end{array}$ \\
\hline (ii) & $\begin{array}{l}\text { 1. Astragalus sungpanensis E.Peter } \\
\text { 2. Astragalus degensis Ulbr. var. rockianus } \\
\text { Peter-Stiba }\end{array}$ & $\begin{array}{l}\text { Yang Jingsheng and Chucheng jiangcuo 1987, } \\
\text { p.630; }\end{array}$ \\
\hline (iii) & Hedysarum pseudastragalus Ulbr. & Karma chos 'phel 1993, p. 448; \\
\hline (iv) & Gueldenstaedtia himalaica Baker & $\begin{array}{l}\text { Dga' ba'i rdo rje 1995, p. 308; } \\
\text { Pasang Yonten Arya 1998, p. 283; }\end{array}$ \\
\hline
\end{tabular}




\begin{tabular}{|l|l|l|}
\hline (v) & Astragalus yunnanensis Franch. & Qinghaisheng yaopin jianyan suo 1996,vol. 1, p. 543; \\
\hline (vi) & Astragalus polycladus Bureau \& Franch. & Luo 1997, p. 128; \\
\hline (vii) & Oxytropis glacialis Benth. ex Bge. & Chen Jiahui and Yang Yong 2010, p. 87. \\
\hline
\end{tabular}

\section{shadrang (sha sbrang)}

One author only provides an identification for shadrang. According to him, it is a certain fly, Atylotus bivittateinus Takahasi, a synonym of Atylotus miser Szilady.

\begin{tabular}{|l|l|l|}
\hline (i) & Atylotus bivittateinus Takahasi & Luo 1997, p. 302. \\
\hline
\end{tabular}

\section{truma (spru ma)}

In Tibetan tradition the plant truma is usually divided into a bright or white type (truma karpo, spru ma dkar po) and a dark or black type (truma nakpo, spru ma nag po). These can be further distinguished by a superior bright type (truma karpo chok, spru ma dkar po mchog) and an inferior bright type (truma karpo menpa, spru ma dkar po dman pa). One author knows of an inferior dark type (truma nakpo menpa, spru ma nag po dman pa) but a superior dark type is not mentioned. Occassionally one finds a yellow type (truma serpo, spru ma ser po). The genera of the identified plants widely vary and include Heracleum, Notopterygium, Valeriana, Angelica, Thalictrum, Aralia and Actaea. Some plant names are still unresolved such as Heracleum wallichii DC. and Heracleum lallii C.Norman. Some are a just synonyms. Heracleum dissectum Ledeb. is a synonym of Heracleum sphondylium subsp. montanum (Schleich. ex Gaudin) Briq. The same can said for Souliea vaginata (Maxim.) Franch. which is Actaea vaginata (Maxim.) J.Compton. The plant Notopterygium forbesii H.Boissieu is an alternative name for Notopterygium franchetii H.Boissieu. The plant name Angelica dahurica var. formosana (H. Boissieu) Shan \& Yuan is a another name of Angelica dahurica var. formosana (Boissieu) Yen.

\section{(A) (truma in general)}

\begin{tabular}{|l|l|l|}
\hline (i) & Heracleum candicans Wall. ex DC. & Institute of Traditional Medicine Services 1999, p. 76; \\
\hline (ii) & Heracleum dissectum Ledeb. & Dašieva, D. B. 2001, p. 727; \\
\hline (iii) & $\begin{array}{l}\text { 1. Heracleum scabridum Franch. } \\
\text { T. Chang } \\
\text { 3. Valeriana fauriei Brig. }\end{array}$ & $\begin{array}{l}\text { Zhongguo kexue yuan xibei gaoyuan shengwu } \\
\text { yanjiusuo 1991, p. 202; }\end{array}$ \\
(iv) & $\begin{array}{l}\text { 1. Notopterygium incisum K.C.Ting ex } \\
\text { 2. Notopterygium forbesii Boiss. }\end{array}$ & Luo 1997, p. 173. \\
\hline
\end{tabular}




\section{(B) (truma karpo)}

\begin{tabular}{|c|c|c|}
\hline (i) & $\begin{array}{l}\text { Heracleum candicans Wall. } \\
\text { ex DC. }\end{array}$ & $\begin{array}{l}\text { Bod rang skyong ljongs gsar brje u yon lhan khang gi 'phrod bsten } \\
\text { cus 1973, p. 337, pl. 196; } \\
\text { Yang Jingsheng and Chucheng jiangcuo 1987, p. 415; } \\
\text { Gurmet Namgyal and Phuntsog 1990, p. 317; } \\
\text { Karma chos 'phel 1993, p. 225; } \\
\text { Dga' ba'i rdo rje 1995, p. 240; } \\
\text { Qinghaisheng yaopin jianyan suo 1996, vol. 3, p. 184; } \\
\text { Luo 1997, p. 172; } \\
\text { Pasang Yonten Arya 1998, p. 137; } \\
\text { Tenzin Dakpa 2007, p. 134; } \\
\text { Bod ljongs sman rtsis khang gso rig zhib 'jug khang 2007, p. 302; } \\
\text { Tsering Dorjee Dekhang 2008, p. 90; }\end{array}$ \\
\hline (ii) & Heracleum lanatum Michx. & Kala 2003, p. 127; \\
\hline (iii) & $\begin{array}{l}\text { 1. Heracleum wallichii DC. } \\
\text { 2. Heracleum candicans } \\
\text { Wall. ex DC. } \\
\text { 3. Heracleum millefolium } \\
\text { Diels }\end{array}$ & Parfionovitch et al. 1992, pp. 71, 73, 229, 237. \\
\hline
\end{tabular}

\section{(C) (truma karpo chok)}

\begin{tabular}{|l|l|l|}
\hline (i) & Angelica dahurica (Fisch. ex Hoffm.) Benth. \& Hook f. & $\begin{array}{l}\text { Yang Jingsheng and Chucheng } \\
\text { jiangcuo 1987, p. 417; }\end{array}$ \\
\hline (ii) & $\begin{array}{l}\text { Angelica dahurica (Fisch. ex Hoffm.) Benth. \& Hook f. var. } \\
\text { formosana (Boiss.) Shan. et Yuan }\end{array}$ & Luo 1997, p. 168; \\
\hline (iii) & Heracleum millefolium Diels & Luo 1997, p. 173. \\
\hline
\end{tabular}

\section{(D) (truma karpo menpa)}

(i) Thalictrum petaloideum L. Luo 1997, p. 83.

\section{(E) (truma nakpo)}

\begin{tabular}{|l|l|l|}
\hline (i) & Aralia atropurpurea Franch. & $\begin{array}{l}\text { Bod rang skyong ljongs gsar brje u yon lhan khang gi } \\
\text { 'phrod bsten cus 1973, p. 339, pl. 197; } \\
\text { Gurmet Namgyal and Phuntsog 1990, p. 317; }\end{array}$ \\
\hline (ii) & Aralia sp. & Tenzin Dakpa 2007, p. 135; \\
\hline
\end{tabular}




\begin{tabular}{|c|c|c|}
\hline (iii) & $\begin{array}{l}\text { 1. Aralia apioides Hand.-Mazz. } \\
\text { 2. Aralia atropurpurea Franch. }\end{array}$ & $\begin{array}{l}\text { Yang Jingsheng and Chucheng jiangcuo 1987, p. 418; } \\
\text { Luo 1997, p. 166; }\end{array}$ \\
\hline (iv) & Heracleum lallii C.Norman & $\begin{array}{l}\text { Pa sang yon tan } 1994, \text { p. } 95 \\
\text { Tsarong 1994, p. 95; }\end{array}$ \\
\hline (v) & Heracleum lanatum Michx. & Kala 2003, p. 127; \\
\hline (vi) & $\begin{array}{l}\text { Angelica paeoniifolia R.H.Shan \& } \\
\text { C.C.Yuan }\end{array}$ & Zla ba mngon dga' 2004, p. 80 \\
\hline (vii) & $\begin{array}{l}\text { 1. Heracleum dissectum Ledeb. } \\
\text { 2. Aralia atropurpurea Franch. } \\
\text { 3. Angelica sp. }\end{array}$ & Parfionovitch et al. 1992, p. 229; \\
\hline (viii) & $\begin{array}{l}\text { Notopterygium incisum C. C. Ting ex } \\
\text { H. T. Chang }\end{array}$ & $\begin{array}{l}\text { Karma chos 'phel 1993, p. } 226 \text {; } \\
\text { Bod ljongs sman rtsis khang gso rig zhib 'jug khang } \\
\text { 2007, p. 304; }\end{array}$ \\
\hline (ix) & Notopterygium forbesii H.Boissieu & $\begin{array}{l}\text { Dga' ba'i rdo rje 1995, p. } 240 ; \\
\text { Pasang Yonten Arya 1998, p. 137; }\end{array}$ \\
\hline (x) & $\begin{array}{l}\text { 1. Notopterygium incisum Ting } \\
\text { 2. Notopterygium franchetii } \\
\text { H.Boissieu }\end{array}$ & Xizang deng weishengju 1979, p. 56; \\
\hline (xi) & $\begin{array}{l}\text { 1. Notopterygium incisum Ting } \\
\text { 2. Notopterygium forbesii H.Boissieu }\end{array}$ & Qinghaisheng yaopin jianyan suo 1996, p. vol. 3186. \\
\hline
\end{tabular}

\section{(F) (truma nakpo menpa)}

\begin{tabular}{|l|l|l|}
\hline (i) & Souliea vaginata (Maxim.) Franch. & $\begin{array}{l}\text { Yang Jingsheng and Chucheng jiangcuo 1987, p. 420; } \\
\text { Luo 1997, p. } 80 .\end{array}$ \\
\hline
\end{tabular}

\section{(G) (truma serpo)}

\begin{tabular}{|c|c|c|}
\hline (i) & Heracleum scabridum Franch. & $\begin{array}{l}\text { Yang Jingsheng and Chucheng jiangcuo 1987, } \\
\text { p. 420; } \\
\text { Luo 1997, p. 173; }\end{array}$ \\
\hline (ii) & $\begin{array}{l}\text { Notopterygium incisum } \quad \text { K.C.Ting ex } \\
\text { H.T.Chang }\end{array}$ & $\begin{array}{l}\text { Dga' ba'i rdo rje 1995, p. 240; } \\
\text { Pasang Yonten Arya 1998, p. } 137 .\end{array}$ \\
\hline
\end{tabular}




\section{trumembu (spru ma'i' 'bu)}

There are just a few scholars providing an identification. Two are of the opinion that is a chrysalis of caterpillars, whereas one also adds a literal rending of trumembu, namely moxa insect.

\begin{tabular}{|l|l|l|}
\hline (i) & caterpillar chrysalis & $\begin{array}{l}\text { Parfionovitch et al. 1992, p. 227; } \\
\text { Pasang Yonten Arya 1998, p. 137; }\end{array}$ \\
\hline (ii) & moxa insect, chrysalis & Clark 1995, p. 182. \\
\hline
\end{tabular}

\section{yokmo (yog mo)}

Two authors identify it with Rabdosia rubescens (Hamst.) C. Y. Wu et Hsuan but it is an incorrect and it is not fully clear which plant is meant. Presumably, they meant Plectranthus rubescens Hemsl. It is a synonym for Isodon rubescens (Hemsl.) H.Hara. All other scholars regard it as an Artemisia species but it varies which one.

\begin{tabular}{|l|l|l|}
\hline (i) & $\begin{array}{l}\text { Rabdosia rubescens (Hamst.) C. } \\
\text { Y. Wu et Hsuan }\end{array}$ & $\begin{array}{l}\text { Dga' ba'i rdo rje 1995, p. 282; } \\
\text { Pasang Yonten Arya 1998, p. 234; }\end{array}$ \\
\hline (ii) & Artemisia spp. & $\begin{array}{l}\text { Dašieva, D. B. 2001, p. 741; } \\
\text { Kletter and Kriechbaum 2001, p. 317; }\end{array}$ \\
\hline (iii) & Artemisia capillaris Thunb. & $\begin{array}{l}\text { Bod ljongs sman rtsis khang gso rig zhib 'jug khang 2007, } \\
\text { p. 524; }\end{array}$ \\
\hline (iv) & Artemisia desertorum Spreng. & $\begin{array}{l}\text { Zhongguo kexue yuan xibei gaoyuan shengwu yanjiusuo } \\
\text { Qinghaisheng yaopin jianyan suo 1996, vol. 2, p. 234; }\end{array}$ \\
\hline (v) & Artemisia nanschanica Krasch. & Chen Jiahui and Yang Yong 2010, p. 146; \\
\hline (vi) & Artemisia stricta Edgew. & $\begin{array}{l}\text { Bod rang skyong ljongs gsar brje u yon lhan khang gi 'phrod } \\
\text { bsten cus 1973, p. 382, pl. 230; } \\
\text { Parfionovitch et al. 1992, p. 73, 229; } \\
\text { Karma chos 'phel 1993, p. 240. }\end{array}$ \\
\hline
\end{tabular}

\section{zindira (zi ldi ra)}

Two authors only deal with zindira. Both are of the opinion that it are Cicadidae.

\begin{tabular}{|l|l|l|}
\hline (i) & Cicadidae & $\begin{array}{l}\text { Parfionovitch et al. 1992, p. 233; } \\
\text { Dašieva 2001, p. 369. }\end{array}$ \\
\hline
\end{tabular}




\section{NOTES}

1. I am grateful to Shane Suvikapakornkul, Serindia Publications, for his generous permission to reproduce details from the Tibetan Medical Paintings. I want to thank Nathan Hill for sending me a rare article on medicinal insects in the Mongolian medical tradition and Jan Seifert for editing the images of this paper. I would also like to extend special thanks to William McGrath for his careful English editing of this essay. I am also thankful to both anonymous reviewers for their amendments, comments and suggestions. All mistakes that remain are my own.

2. Alves et al. 2014.

3. Alves \& Rosa 2005, p. 2.

4. Still 2003, pp. 118ff., Alves \& Rosa 2005, pp. $2 \mathrm{ff}$.

5. Feng et al. 2009, p. 315.

6. Lokeshwari \& Shantibala 2010.

7. Costa-Neto 2005, pp. 105ff., Feng et al. 2009, p. 314, Mans et al. 2016.

8. Shrivastava \& Prakash 2015.

9. Wang 1989, Costa-Neto 2005, p. 107, Verma \& Prasad 2012, Mans et al. 2016, pp. $386 f$.

10. Still 2003, p. 118.

11. Alves \& Rosa 2005, p. 2.

12. Feng et al. 2009, p. 313.

13. Ibid.

14. Unnikrishnan 1998, p. 2. On both texts, see Wujastyk 2003, pp. 39ff., $104 \mathrm{ff}$.

15. Mahawar \& Jaroli 2008, p. 10.

16. Meyer-Rochow \&Chakravorty 2013.

17. Regarding the medical texts from Turfan, see Francke 1924a, 1924b, 1925, Hübotter 1928, Taube 1980, pp. 73ff. For medical texts from Dunhuang, see Yoeli-Tlalim 2013, 2015. A modern edition was edited by Luo 2002. The Turfan texts are in the data base The International Dunhuang Project: The Silk Road Online under the numbers: TibHT 1, TibHT 24, TibHT 25, TibHT 26. The same database has the Dunhuang texts under the numbers Pelliot tibétain 127, Pelliot tibétain 1044, Pelliot tibétain 1058, IOL Tib J 1246 (former number I.O. 56, 57) and IOL Tib J 756.

18. See Beckwith 1980, Yoeli-Tlalim 2013.

19. See Akasoy \& Yoeli-Tlalim 2007.

20. This can be found in virtually all medical treatises. It was a standard procedure.

21. The Four Tantras consists of the Root Tantra, the Explanatory Tantra, the Instructional Tantra and the Subsequent Tantra.

Explanatory Tantra of his fundamental work, the Four Tantras.

22. Parfionovitch et al. 1992, pp. 75ff., 231ff.

23. Shel gong shel phreng $384 / 11,390 / 17,396 / 22,400 / 18,408 / 13,410 / 16$. For references, see appendix.

24. Shel gong shel phreng 382/11, 384/11, 385/6, 388/14, 390/15, 394/11, 400/18, 410/16, 413/21. For references, see appendix.

25. The information that Jampel Dorjé bears the monastic name Yeshé Döndrup Tenpé Gyemtsen can be found in the colophons of his works, Mdzes mtshar mig rgyan A I 347/3, Mdzes mtshar mig rgyan B I, p. 24 fol. 2 (47a/3), 347/3. In the latter, he states that he used a Chinese pharmacopeia (bencao) for the illustrations of his treatises, Mdzes mtshar mig rgyan B I, p. 24 fol. 1 (46b/2). It is obvious that he used one of the many versions of the Bencao Gangmu. There are several articles on his life and writings, see, for instance, Bao et al. 2004, Bao 2010. See also Hofer 2014 but note that she did not make full use of the colophons and did not consult the academic literature on Jampel Dorjé written by Chinese, Mongolian and Russian scholars. 
26. The Tibetan designations are: 1. khron gyis brko ba'i sde, 2. mchu yis brko ba'i sde, 3. ri dwags kyi sde, 4. gcan gzan gyi sde, 5. mthus za ba'i sde, 6. mi yis bdag byed pa'i sde, 7. khung du gnas pa'i sde and 8. rlan du gnas pa'i sde.

27. rGyud bzhi 54/13.

28. These are: 1 . The category of animals digging with their claws (khron gyis rko ba'i sde), 2. The category of animals digging with their beaks ( $m c h u$ yis rko ba'i sde), 3. The category of herbivorous animals ( $r i d w a g s s d e$ ), 4. The category of large herbivorous animals ( $r i d w a g s$ che ba'i sde), 5. The category of carnivorous animals (gcan gzan sde), 6. The category of animals eating with force ( $r$ tsal mthus za ba'i sde), 7. The category of animals domesticated by men (mi yis bdag byed sde), 8 . The category of animals living in dens and burrows (khung gnas sde) and 9. The category of animals living in water and damp locations (rlan la gnas pa'i sde).

29. In the opinion of Dash, both first categories of animals digging with their claws and animals digging with their beaks should be seen as a single category; Dash 1994-2001, vol. 3, pp. 50f.

30. gZhan la phan gter 394/2.

31. gSer gyi thur ma 74/17.

32. Srikantha Murthy 2004-2005 [1992-1997], vol. 1, pp. 83ff.

33. In the Aștāngahṛaya-saṃhitā, these eight categories are: 1. mrga (ri dwags), 2. vișkira (khron rko), 3. pratuda (mchus rko), 4. bileśaya (khung na gnas), 5. prasaha (rtsal mthus za), 6. mahā-mrga (ri dwags che), 7. apcara (chur gnas), 8. matsya (nya) (the Tibetan equivalents have been copied from Tibetan translations of the Aștāngahṛdaya-saṃhitā.) The designations can be interpreted and rendered in different ways depending on the animals that are grouped into a category. For instance, the standard translation for the term mrga would be "a deer, an antelope", but this would be an inaccurate rendering for the animals that are united in this group. Zimmermann therefore chooses the translation "quadruped" and "quadruped game" as the only acceptable rendering for $m r g a$, as it is the only umbrella term fitting for all animals equally, Zimmermann [1982] 1999, p. 60.

34. Zimmermann [1982] 1999, pp. 100, 103 etc., Olivelle [2002] 2011, pp. $377 f$.

35. ka la nta ni / shin tu ltas bzang gi dus su 'babs pa'i bye'u ste / lus che ba dang kha dog snga lnga'i sgro spu shin tu mdzes pa / skad snyan pas rna can 'phrog pa dang / lding na bya byi'u thams cad rjes su 'brangs pa yin te / shel gong las / de pho phug ron ka lanta ka'i mgos / ro tsa rem la rma gso rdzas 'gar mchog / ces so / skad snyan pa'i bye'u phug ron 'dra la ljang gu ka la pingga dang ma nor ba dgos so, mDzes mtshar mig rgyan A I 223/1.

36. This also has the name Kalandaka. Dave identifies it as chestnut-bellied nuthatch (Sitta castanea) and subspecies, Dave [1985] 2005, pp. 26, 487.

37. This meaning mainly applies in Buddhist literature. It can also be used as a generic term for sparrow-like birds with a sweet voice, Dave 2005, pp. $94 \mathrm{f}$.

38. The broad medicinal use of honey in the Tibetan medical tradition deserves a separate study. It will therefore not be discussed in this article. For references regarding its identification, see appendix.

39. In this regard, one has to note that both Western and Tibetan authors usually are simplifying nosological categories by equating Tibetan disorders with Western diseases. For instance, if a certain plant is, according to Tibetan medicine, said to cure "liver diseases", one usually finds the literal "translation" of liver diseases as it is understood in Western medicine, even though both entail differences in detail. The symptoms and classifications of diseases according to Tibetan medicine do not correspond to Western biomedicine and would be insufficient for a valid diagnosis from a Western perspective. In other words, a diagnosis made by a Tibetan doctor is not necessarily identical with a diagnosis made by a Western doctor and, for instance, a patient with a "liver disease" in Tibetan medicine could completely differently diagnosed in Western medicine. This important problem is often not adequately addressed in research. For a notable 
exception see, for instance, Kletter \& Kriechbaum 2001. In this article, diseases will therefore be put in quotation marks.

40. I have chosen these insects because they are mentioned in various Tibetan medicinal sources and in Tibetan texts on materia medica. It is possible that there are a few more I did not come across.

41. sha sbrang mig po che bubs gcig, Bye ba ring bsrel 374/9.

42. $m$ Gul rgyan 754/12, 'Chi med nor bu'i phreng ba 76/2, Man ngag snying gi nor bu 131/4.

43. Zin tig mdzes rgyan $278 / 20$.

44. Bod rang skyong ljongs sman rtsis khang 2005, p. 825.

45. For the reference, see the appendix.

46. Given the misspelled name Eormica fusca L., it seems that rNam rgyal thar 2006 and dGra 'dul 2009 simply copied dGa' ba'i rdo rje 1995.

47. grog ma ni / raksha mig med / rgyu rgyur / gshin rje'i bu zer / mgo dang stod smad so sor chad cing nag po rkang drug khug nas byung ba'o / rgya gar du de'i khungs mkhar ba lhar [ltar] che bas gas pa 'dug mod / shel sgong las / raksha mig med rtsa 'byed dmu chu sbyong / zhes gsungs, mDzes mtshar mig rgyan A I $257 / 1$.

48. raksha mig (grog ma yin) med rtsa 'byed dmu chu sbyong, Shel gong shel phreng 422/15.

49. For more information, see Kletter \& Kriechbaum 2001, p. 343.

50. srog chags grog ma la spyir ming lnga 'dir raksha / mig med dang gnyis des rtsa kha 'byed la dmu chu sbyong, Vaidūrya sngon po 340/3.

51. de'i tshang gi sas sha skrangs 'joms, Vaidūrya sngon po 340/4.

52. Srikantha Murthy 2004-2005 [1992-1997], vol. 2, p. 507. Cf. also Cakrapanidatta 1999, p. 244.

53. Parfionovitch et al. 1992, pp. 75f., 231f. Note that the painter mistakenly depicts the ant (or termite) with eight legs instead of six legs. In this regard, it resembles more a beetle than an ant. It is, however, correctly depicted in Jampel Dorjé's illustrated treatise showing this insect with six legs.

54. raksha chur bsdus srod la khyor gang btang / khams 'khrugs lus lci phrum ser khyer na yin, rGyud bzhi $517 / 3$.

55. ru raksha drag po'i mig ces zur chag pa rag sha ste mig med lnga chur bsdus pa'o, sKyem pa Tshe dbang 'Grel pa vol. 3 519/16, raksha ste drag po'i mig ces zur chag pa'i ru raksha lnga chur gdus pa srod la khyor gang btang bas khams 'khrugs zhes sems 'khrug cing lus po lci la phrum ser khyer zhes grang shum byed na dug yin, Vaidūrya sngon po 1081/17.

56. ru raksha drag po'i mig ces zur chag pa rag sha ste mig med lnga chur bsdus pa la bshad na'ang / zhes bla rtas gsung [gsungs] kyang rang lugs ni srog chags grog ma la bzhed do, Mes po'i zhal lung sMad cha 673/1; raksha ni raksha mig med pa lnga chur gdu, mKhas pa'i zhal lung 495/12; raksha mig med pa lnga chur bsdus, Phan bde'i sgo 'byed lde mig 375/6. The term "eyeless demons" (raksha mig med) is normally understood as a term for ants. Although the interpretation raksha seeds without eyes is much less probable, the latter can serve as a quality attribute.

57. Man ngag lhan thabs 594/1, Man ngag lhan thabs brda bkrol 197/20.

58. raksha ni ru raksha lnga zhes bai sngon dang srog chags grog ma lnga zhes bla rta ltar dka' 'grel lo, A ru ra'i phreng ba'i mdzes rgyan I 408/9, A ru ra'i phreng ba'i mdzes rgyan II 473/7. He wrongly attributes the opinion that ants are meant to Lata (Bla rta), i.e. Kyempa Tsewang.

59. brag dkar (bya rgod sha) bdud rtsi brag (sbrul sha) 'og rtsi / chu yi (nya khyi ba) bdud rtsi rdo 'og (grog ma dmar po) rtsi / chu glang (sbal pa) brag gi glang bu (rtsangs pa) dang / shing kun de rnams phye ma ni / thor pa sod par byed pas byug, Zla ba'i rgyal po 192/13.

60. yang 'brum bcos kyi gsang sman ni / rang shi'i rkang mar 'brum lkog [skogs] gnyis la byed / la las srog chags grog ma drug bdun tsam re mar 'dril gyur [khyur] myid byed pa dang, Zhal shes snying gi khu ba $382 / 15$.

61. chu 'dren gsang sman / raksha mig med [grog ma] sbyang shis cha drug la / srad dkar skyu ru glang sna [lug ru dmar po] nyi dga'i 'bru / gur gum 'jib rtsi ba chu'i khanda rnams / thun re zhib btags sbrang 
rtsis ril bu ni / sran spos tsam dril lnga bdun chu tshan phul / tsha chu grang chu la sogs chu rigs kun / 'dren skem the tshom bral ba'i gsang sman yin, Man ngag rin chen 'byung gnas 94/2.

62. zho sbur la spyi dang 'dir ming gcig 'khrul med sbur chung des chu ser la phan, Vaidūrya sngon po $349 / 22$.

63. Le 'dod mos 2009, p. 294. In modern usage the term "yellowish fluid" is often used to denote serum or lymph.

64. rGyud bzhi 339/11.

65. sbur ba ste zhod sbur, Vaidūrya sngon po 777/1.

66. zho sbur ni / sbur chung myur mgyogs can de'o, A ru ra'i phreng ba'i mdzes rgyan I 130/7, A ru ra'i phreng ba'i mdzes rgyan II 138/19.

67. zho sbur ni / dbyar du zho rnying ba nas grub pa'i 'bu zhig gam snyam mo / bai sngon las / zho sbur zhes $\mathrm{pI}$ sbur chung ni chu ser la phan par bshad, mDzes mtshar mig rgyan A I 256/2.

68. sbur pa se sbur ro, sKyem pa Tshe dbang 'Grel pa 265/16; sbur ba ni bse sbur, mKhas pa'i zhal lung 394/15.

69. sbru pa ni gser sbur nag po, Phan bde'i sgo 'byed lde mig 270/4.

70. For references, see the appendix.

71. spru ma'i 'bu ni / spru ba dkar nag gnyis / dkar po ste/ gdugs dkar can gyi 'bu'o, rGyud bzhi'i rtsa 'grel $186 / 4$

72. spru ma'i 'bu khra bo de yi rma yi khrag shor ba sdom mo, sKyem pa Tshe dbang 'Grel pa 444/3.

73. spru dkar gyi dkyil du gnas shing 'tsho ba'i 'bu khra bo, Dri med kun gsal 105/10.

74. spru ma la rigs dkar nag gnyis su phye ba 'di dkar po de'i rtsa ba'am gseb tu gnas pa'i 'bu khra bo che chung mthe bong tsam pa de yis ni, Gser mchan 843/13.

75. spru ma'i 'bu ni spru dkar gyi rtsa bar ston dus 'bu sngo khra yod pa de yin, mKhas pa'i zhal lung 282/19. See also Drang srong zhal lung vol. $1564 / 21$.

76. spru ma'i 'bu ni / spru dkar 'bu / shu ta dye pa zer / spru dkar gyi lo mar yod pa'i 'bu ste / rgyud las / spru ma'i 'bu yis rtsa khrag shor ba sdom zhes gsungs / so, Mdzes mtshar mig rgyan A I 256/1.

77. For references, see the appendix.

78. Yonten Gonpo 2011a, p. 217.

79. spru ma'i 'bu yis rtsa khrag shor ba sdom, rGyud bzhi 75/12. Clark 1995, p. 117, Yonten Gonpo 2011a, p. 217.

80. spru ma'i 'bu la spyi dang 'dir ming gcig / de yis rtsa'i khrag shor ba khong nas sdom, Vaiḍūrya sngon po $322 / 7$.

81. spru ma dag la rnam pa gnyis, Vaidūrya sngon po 328/18, shu ti zhes pa 'u su nag por bzhed na'ang spru 'bru, Vaidūrya sngon po 700/15, shu ti zhes spru ma'i 'bru, Vaidūrya sngon po 798/2.

82. spru ma'i 'bru yis rtsa khrag gcod, 'Bum bzhi vol. 1 249/16

83. spru 'bu bcos nas spru 'bru byas nor, Kun gsal snang mdzod 840/4.

84. spru ma, Shel gong shel phreng $271 / 8$, sbur khras khyi dug spru 'bus khrag shor sdom, Shel gong shel phreng 420/14.

85. phye ma leb ni / stag khra / bye stag khra / bye stag / lhung byed zer / me 'od la chags nas bsags pa kha dog sna tshogs yod pa'ang dgos pa ser khra lus phra chung 'dab bzhi pa mdog bris pa ltar shin tu rnon po'o / shel gong las phye leb ser khras so srin nywa log sel / zhes so, Mdzes mtshar mig rgyan A I 256/3.

86. For references, see the appendix.

87. Phan bde'i sgo 'byed lde mig 248/14, 275/1, sKyem pa Tshe dbang 'Grel pa 232/11, 274/10, Mes po'i zhal lung sMad cha 326/3, 390/21, Vaidūrya sngon po 706/18, 788/3, mKhas pa'i zhal lung 377/8, 398/3, A ru ra'i phreng ba'i mdzes rgyan I 245/6, 281/12, Drang srong zhal lung vol. 2 705/11, vol. 3 $144 / 14$.

88. bye stag la spyi dang 'dir ming gcig / de'ang phye ma leb ser khra'i shas so srin dang / nywa log la phan, Vaịūrya sngon po 349/21.

89. Shel gong shel phreng $421 / 20$. 
90. Le 'dod mos 2009, p. 1117. Today the tiny beings known as sin (srin) are often interpreted as bacteria and viruses. They are also regarded as worms or parasites.

91. Le'dod mos 2009, p. 339.

92. de ma 'dzom na cha ga ni rigs che chung kha dog gi dbye ba mang yang nus pa mtshungs, sKyem pa Tshe dbang 'Grel pa vol. 3 295/1.

93. cha ga ba ni lte chag gam / tshag tshag pa'am / lte ba san cag gam / seng phrug gnam 'phyogs zhes pa, Bdud rtsi sgron me 278/7, cha ga pa ste lte ba ca cag / seng phrug gnam mchong bong, sKyem pa Tshe dbang 'Grel pa vol. 2 535/12, mi cha gdab / lte cag pa / chag chag pa / seng phrug gnam mchings / zhes sogs so, sKyem pa Tshe dbang 'Grel pa vol. 3 295/1, cha ga pa ste lte ba cag cag / seng phrug gnam 'tshong ('chong), Mes po'i zhal lung sMad cha 683/11, cha ga pa zhes pa'am / re lcag pa / te ba phan cag seng 'brug gnam mchong / tshag tshag pa sogs su grags pa, Mes po'i zhal lung sMad cha 971/1, cha ga ni cha ga pa ste pa pan cag / seng 'phrug gnam 'phyong / yul skad du tshar tsha' zer, A ru ra'i phreng ba'i mdzes rgyan I 488/6, de ma 'dzom na cha ga pa zhes sam seng phrug gnam mchong tshag tshag pa sogs su grags pa, Drang srong zhal lung 315/1, de ma 'dzom na cha ga'i mgo zhes cha ga ni tshags pa rkang dmar zer ba skad rtsub pa man rgyud rma'i skabs su khyung phrug skyugs pa'i kha chu zer ba de mar khu skyugs pa phyi rgyud rtsa'i byid po'i skad ltar thung la rtsub pa 'phar zhes byid po ni 'di dngos yin par mkhyen gzigs nas gsungs, mKhas pa'i zhal lung 676/5.

94. cha ga pa la spyir ming lnga 'dir gcig de ni ston ka spang du 'ong ba de phur ba'i kha chu bdud rtsi smug po zhes pas klad pa'dzag pa gcod cing rtsa nad 'jam par sbyong, Vaidūrya sngon po 345/5, cha ga pa zhes sam te ba ban cag seng 'brug gnam mchong / tshag tshag pa sogs su grags pa'i mgo bo bsdeb pa dang, Vaidūrya sngon po 1337/1.

95. cha ga pa ni / cha ga pa zer / mtho bong tsam yang ring / skya smug nag thig can 'dab ma dmar po lding na sgra 'byin zhing rkang drug gi phyi ma ring ba dang de'i kha chu la bdud rtsi smug po zer / rgya nag tu shin tu mang pos lo thog za ba'ang 'dug / shel sgong las / chu sbur bshad de / de bzhin cha ga'i mgo yis byang dug 'joms / bdud rtsi smug pos klad pa'dzags pa gcod / zhes gsungs so, Mdzes mtshar mig rgyan A I 263/1.

96. For references, see the appendix.

97. rGyud bzhi 532/2.

98. rGyud bzhi 624/2. Dašiev 2001, pp. 617ff, Yonten Gonpo 2011b, pp. $193 \mathrm{ff}$.

99. rGyud bzhi 624/17. See also rGyud chung 818/2.

100. Bye ba ring bsrel 274/10.

101. Dug srung rim pa $470 / 8$.

102. For references, see the appendix.

103. lte mkhrang nad la gla rtsi byi tang ga / ma ru tse dang smyug rtsi pi pi ling / phur thal sdig srin dri chus sbyangs la btang / zi ldi sbur thal pha ma'i skra gzhob bzhi / byis pa'i chur sbyangs btang bas sel bar 'gyur, rGyud bzhi 371/4.

104. zi ldi ni zi ldi ra sbur pa chen phur shes mchu [chu?] dug 'byung ba de'o / sbur pa ni bse dri can no / 'di gnyis nus bsreg byas pha dang ma gnyis ka'i skra gzhob dgos so, sKyem pa Tshe dbang 'Grel pa 297/17.

105. zin [zi] ldi zhes pa zi de ra sbur ba chen po phur shas chu dug 'byung ba de'o / sbur ba zes pa ni gseb dri can no / 'di gnyis nus ldan du bsregs byas pho dang mo gnyis ka'i skra bzhob [gzhob] dgos so, Mes po'i zhal lung sMad cha 427/9.

106. zi ldi ra la spyi dang 'dir ming gcig de'ang ngo bo che la lo bzhi dbyar du dbyar nyi ldog nad 'byung ba de dang / chung ba nam du 'byung ba des rang gi chu nad dang gnyan rigs byis pa'i lte mkhrang la phan, Vaidūrya sngon po 345/2.

107. yang na zi ldir dang sbur ba gnyis nus ldan bsregs thal dang phru gu'i pha ma'i skra gzhob bzhi byis pa'i dri chur sbyangs la btang bas sel bar 'gyur, Vaidūrya sngon po 826/6.

108. zi ldi ni dbyar nyi ldog dus byung ba'i sbur ba chen po ser nag 'phur shes pa de nyid chu nang du song na chu dug 'byung ba ming ldang gog lding gog gam zi di [ldi] ra zer ba de'o// sbur ni sbur pa nag po bse dri can de'o // thal ni nus ldan bsreg / lte rnag dang po la bu rang gi lte ba bcad pa skam po'i phye ma gdab, Phan bde'i sgo 'byed lde mig 287/16. 
109. zi ldi ni zi ltir ste / bee sngon las / ngo bo che la lo bzhi bar du dbyar nyi ldog nad byung ba de dang chung ba nam du'ang 'byung zhes bshad la / zi ldi spur thal zhes pa'i thad kyis dka' 'grel las / zi ldi zhes pa zin dir sbur ba chen po phur shes chu dug byung ba de'o / sbur ba zhes pa ni gsi pa dri can no / 'di gnyis nus ldan bsregs zhes bshad do, A ru ra'i phreng ba'i mdzes rgyan I 128/18, A ru ra'i phreng ba'i mdzes rgyan II $137 / 8$.

110. zi ldi ni zin [zi] ldir te / sbur ba chen po rwa can phur ['phur] shes chu dug can gyi sar byung / sbur ba ni bse dri mnam pa'i sbur ba, A ru ra'i phreng ba'i mdzes rgyan I 294/16, A ru ra'i phreng ba'i mdzes rgyan II 349/17.

111. zi ldir ni / gser rgyan las / zil [zi] der [ldir] spur [sbur] ba chen po 'phur shes chu dug las byung ba de'o / zhes dang bai sngon las / ngo bo che la lo bzhi dbyar dus dbyar nyi ldog nang 'byung ba dang / chung ba nam du yang 'byung ba des rang gi chu nang dang gnyan rigs byis pa'i lte mkhrang la phan bshad / de yang che ba 'phur na sgra cir car bsgrogs te / rgya ser smug che chung bse spur [sbur] tsam shing la yod / chung du rgyab gser 'dra ba mthe chung sen tsam bye mar mang po 'phur yod, Mdzes mtshar mig rgyan A I 255/1, Mdzes mtshar mig rgyan A II 241/9

112. zi ldi ra ni khyi spos pa dang / sbur ni bse sbur gnyis nus bsregs thal / rnag tu khug na phug pa sa 'tsho bar 'gyur/ zhes shes par bya, mKhas pa'i zhal lung 408/18.

113. bse sbur ni / sbur ba nag po'o, rGyud bzhi'i rtsa 'grel 186/2, bse sbur ni nag gseb dri can te / sbu lam pa zhes kyang bya'o, sKyem pa Tshe dbang 'Grel pa 443/23, bse mo sbur gog dang bying bying thu lu gnyis kyis srin glang 'thab drag po'i nad 'joms par byed, Dri med kun gsal 105/8, bse dri mnam pa'i sbur ba, Vaidūrya sngon po 322/2, bse sbur zhes bse dri mnam pa'i sbur ba de dang, Don gsal nyin byed 439/16, bse sbur ni sbur nag bse dri can dang, Drang srong zhal lung vol. 1564/18.

114. bse sbur ni nag po rgyab ser zhad can dru dug pa, Si tu sMan ngo gsal byed 115/2, bse sbur ni nag po rgyab ser zhad can dri shin tu dugs pa, mKhas pa'i zhal lung 282/17.

115. bse sbur ni sbur ba dri ma can nam bse dri sbur gog ces pa de'o / 'di la rigs ni che 'bring chung gsum 'byung ngo / kha cig ni so ka'i dus su nyin sa'og tu mi mngon par sdod cing srod dus bar snang dang shing rtser lding ba'i ming zi ldir ba zhes che chung gnyis yong ba de la bzhed / kha cig ni sa yi g.yag rgod stobs che'am ming gzhan ka go [ko] g.yag ces pa che chung gnyis yong ba de la bzhed cing / de dag rnams kyang mi 'thad pa ni ma yin te / ro nus sogs mtshungs pas so / ngo bo ni sngar bshad pa de dang, gSer mchan $843 / 4$.

116. bse sbur ni / spur rog po zer / bai sngon du drin mnan pa'i spur ba zhes pa nag srab mthe bong tsam rkang drug pa / 'og sgo nas bse dri 'dra byung ba de'o / rgyud las / bse spur bying bying thu lus glang thabs 'joms zhes so, mDzes mtshar mig rgyan A I 255/3.

117. There is some disagreement regarding what sebur is. One author indicates that it refers to beetles of the Blaps genus. Another states that is a species of dung beetle. Parfionovitch et al. 1992 gives a slightly confusing statement by saying that it refers to beetles (Coleoptera), but then adds stink bugs. Indeed, many scholars consider sebur to be Nezara viridula, a plant-feeding stink bug. This also applies to Luo 1997, but he provides a further possible identification, which is a certain species of dung beetle. Clark 1995 differs significantly by providing three potential identifications, namely the oriental cockroach, the American cockroach, or a species of dung beetle. For references, see appendix.

118. Zla ba'i rgyal po 168/3.

119. bse sbur bying bying thu lus glang thabs 'joms, rGyud bzhi 75/11.

120. Kletter \& Kriechbaum 2001, p. 347, Semichov 1981.

121. Bye ba ring bsrel 106/11, 417/13, Man ngag rin chen 'byung gnas 593/12.

122. Bye ba ring bsrel 106/11, 'Bum khu tshur 365/19, Man ngag rin chen 'byung gnas 248/6, 593/12, $597 / 10$.

123. bse sbur ni nag gseb dri can te / sbu lam pa zhes kyang bya'o / bying bying thu lu ni rdzib ci zho la zhes kyang bya ste / sbur khog dri can rgyab yol yod pa lta bu'o / nus pa ni gnyan srin gyis skyed pa'i glang thabs 'joms so, sKyem pa Tshe dbang 'Grel pa 443/23. See also the statement made by Sönam Yeshé Gyentsen, where he writes that it cures "colics" caused by distrurbance of internal "small 
animals", bse mo sbur gog dang bying bying thu lu gnyis kyis srin glang 'thab drag po'i nad 'joms par byed, Dri med kun gsal 105/8.

124. Kletter \& Kriechbaum 2001, p. 349.

125. zi ldi spur thal pha ma'i skra gzhob bzhi / byis pa'i chur sbyangs btang bas sel bar 'gyur, rGyud bzhi $371 / 5$.

126. yang na zi ldir dang sbur ba gnyis nus ldan bsregs thal dang phru gu'i pha ma'i skra gzhob bzhi byis pa'i dri 826/6, bse sbur, Vaidūrya sngon po 1393/18.

127. bse sbur zhes pa bse dri mnan pa'i sbur gyis gnyan tshad sel zhing byis pa'i lte mkhrang la phan / bying bying thu lus chu 'gags 'bigs shing / yang 'di dang bse sbur gnyis kyis glang thabs 'joms, Shel dkar me long 222/16.

128. bying bying thu lu ni/ 'ga' zhig sbrang bur'dod pa dang / 'ga' zhig dmar nag rkyal ba la 'dod pa sogs byung yang / zi ldi ra ba'o, rGyud bzhi'i rtsa 'grel 186/2.

129. bying bying thu lu ni rdzib ci zho la zhes kyang bya ste / sbur khog dri can rgyab yol yod pa lta bu'o, sKyem pa Tshe dbang 'Grel pa 444/1.

130. bying bying thu lu ste ming gshog mo rdza log ces pa gshog pa'i rnam pa can yod med gnyis yong ba de gnyis kyis srin glang thabs kyi rigs rnams 'joms so, gSer mchan 843/11.

131. bying bying thu lu ni 'bu mjug ma ra gnyis yod pa'i rgyab gnyer ma can leb mo de yin, Si tu sMan ngo gsal byed $115 / 3$.

132. bying bying thu lu ni 'bu mjug la rwa gnyis yod pa'i rgyab gnyer ma can leb mo de yin, mKhas pa'i zhal lung 282/18, bying bying thu lu ni 'bu mjug mar ra gnyis yod pa rgyab gnyer ma can de, Drang srong zhal lung vol. 1 564/19.

133. bying bying thu lu ni / rdzib rdzib / zhol spur ba zer / bse 'bur nas che sgor mo rkang drug 'dab ma can / lding nus pa mi 'brun ril mor byas nas khung du khyer ba de yin nus pa gong ma dang mtshungs, mDzes mtshar mig rgyan A I 255/4.

134. For references, see appendix.

135. bse sbur bying bying thu lus glang thabs 'joms, rGyud bzhi 75/11.

136. Zla ba'i rgyal po $167 / 17$.

137. Man ngag rin chen 'byung gnas $248 / 7$.

138. rGyud bzhi 329/4.

139. sdig srin chu sbur gnyis kyis chu 'gags sel, rGyud bzhi 75/11.

140. Shel gong shel phreng $421 / 5$.

141. sbur mgyogs ni chu nang du myur du rgyud pa'i sbur chung nag po ste chu sbur zhes so, bDud rtsi sgron me 278/6, chu sbur ni chu la gnas pa'i sbur pa skad cig kha gting du rgyu nus pa ste sbur mgyogs zhes pa de'o / 'di gnyis kyi nus pa ni chu 'gags pa 'byin no, sKyem pa Tshe dbang 'Grel pa 443/21, chu sbur ni sbur mgyogs kyang zer / chu'i dkyil du gnas pa'i sbur chung de nyid yin / de gsum kas dri chu 'gags pa sel bar byed, Dri med kun gsal 105/6, sdig srin la spyir ming dgu 'dir gcig tu 'dod pa dang / chu nang gi sbur ba myur bar 'gro ba'i sbur chung la spyi dang 'dir ming gcig de gnyis kyis chu 'gags pa sel zhing chu sbur gyis khyad par du rtsa nad 'jam por sbyong, Vaidūrya sngon po 322/1, chu sbur ni chu bar nas shin tu mgyogs par rgyug pa'i 'bu chung ngu nag po sre nyams can de yin, Si tu sMan ngo gsal byed 115/2, sdig srin dang chu sbur zhes pa chu nang du myur bar 'gro ba'i sbur chung gnyis kyis chu'gags sel zhing / chu sbur rgyis rtsa nad 'jam por sbyong, Shel dkar me long 222/15, chu sbur ni chu yi ba shin tu mgyogs par rgyug pa'i 'bu chung ngu nag po sre nyams can de yin, mKhas pa'i zhal lung 282/15.

142. chu sbur ni / ljon mo myur mgyogs rta zer / bai sngon las / chu nang du myur bar 'gro ba'i sbur chung zhes pa char chu las grub cing rgas na sbal chung 'gyur te / der tshe gcig lus gnyis dang / sbal ba mjug ma can zer / de phyis sbal bar 'gyur ro / rgyud las / sdig srin chu sbur gnyis kyis chu 'gags sel / zhes gsungs so, mDzes mtshar mig rgyan A I 262/2.

143. The Mongolian term is qoruqai sinayan, the Manchu is koki, and the Chinese is kèdǒu (蝌蚪).

144. One scholar gives a family of water beetles. Others are more specific and identify it as Cybister tripunctatus orientalis Gschwendtner, which is a synonym for Cybister tripunctatus lateralis Fabricius, thus a genus within this family. For references, see appendix. 
145. rGyud bzhi 543/13.

146. chu sbur gyis khyad par du rtsa nad 'jam por sbyong, Vaidūrya sngon po 322/2.

147. Man ngag rin chen 'byung gnas $128 / 8,611 / 7$.

148. For references, see appendix.

149. ming gzhan padme zhes so, bDud rtsi sgron me 276/12, ming gzhan pad me'u dang rgya nag me lce 'khor lo / rgya grog dmar po zer ba'ang snang, sKyem pa Tshe dbang 'Grel pa 443/6, ming ni padme stag chung / dmar khra byang khra padma [padme] can dang / hor gdan ser po sogs so, gSer mchan 842/14, byang pa ni / brang ha la / stag chung dmar khra / mo nad dpa' bo zer, Mdzes mtshar mig rgyan A I $262 / 1$.

150. Zin thig yang thig 502/14, rGyud bzhi'i rtsa 'grel 186/1, bDud rtsi sgron me 276/12, sKyem pa Tshe dbang 'Grel pa 443/6, Dri med kun gsal 104/17, gSer mchan 842/14, mDzes mtshar mig rgyan A I 262/1.

151. byang ba nag khra kun la dug yod pas spang ngo, 'Bum khu tshur 289/11, rigs ni nag dmar ser po khra / rim par sngar bzang cher rje'i lugs / kho bo'i nyams len 'di rang ngo / zla ba thigs par nag khra chug [chung] / dug yod pa ni spang ngo zer / dmar khra snyoms la ser khra brdul [rtul], Zin thig yang thig $502 / 14$.

152. nag po gsum dang dmar khra bdun mnyam / dmar khra bdun dang ser khra bcu gcig mnyam pas bzang ngan gyi nus pa khyad par de dang bstun pas, Dri med kun gsal 104/17.

153. Zin thig yang thig 502/19, 'Bum khu tshur 289/11, rGyud bzhi 624/16, Yid bzhin nor bu 96/17, Bye ba ring bsrel 121/11, Bye ba ring bsrel 426/15.

154. la la mgo lag 'dreg ['breg] zer te / mgo lag med na gang med kyi / nad mi 'grangs ['drongs] pas mi 'dreg ['breg] go, Zin thig yang thig 502/20.

155. byang pa mgo rkang chad na nad 'drongs chung, rGyud bzhi 624/17.

156. dmar khra bar gshog ldan pa nyi shu gcig / gshog dkar phral na rno myur ga la srid, Bye ba ring bsrel $121 / 11$.

157. rje g.yu thog pa'i shog dril skor gsum las sbyong gi sde tshan skor du / sug smel gyis pho ba'i gzhi 'dzin / gur gum gyis mchin pa skyob / shri khandas bungs che zhing gnyug ring du 'khru / dong ga'i 'khor los 'khor zhing 'khru / dan das rgyug / sngon bus 'khrog dug phyid [byid] dpa' bo stobs dang ldan / rgya tshas 'bigs / byangs bas 'ded / sdig srin nad rnams rtsa lam 'khrid / bye mas gnon / thang chus (attached note: dkar po) rtsa lam 'byed / bul tog gis na tsha med, Phan bde'i bang mdzod 252/12.

158. It is likely that the "wheel of iron" is the secret name of an ingredient. As a note is not attached, it remains unresolved what kind of materia medica it is.

159. shig khra gshog bor rnam pa (note: byang khra) bdun / sbur 'gyogs (note: ser po) gcig gi rta la bskyon /lcags kyi 'khor lo phyag na bsnams / dung gi (note: rgya tshwa) / ber ga gser gyi (note: gsar bye ma) zhwa / zhib btags chang gis cung pos phul, gSer bre chen mo II 209/13.

160. Zla ba'i rgyal po 232/12.

161. gSung sgros $19 / 1$.

162. Zin thig yang thig $501 / 1$.

163. For these and the following schools, see Desi Sangyé Gyatso 2010.

164. gSer bre chen mo I 297/2, gSer bre chen mo II 209/13, dNgul bre ma 174/1.

165. Yid bzhin nor bu 96/7, Bye ba ring bsrel 110/6, 121/7, 195/10.

166. bDud rtsi'i thigs pa 484/4.

167. For a translation of Yönten Gönpo's treatment, see Dašiev 2001, pp. 617ff, Yonten Gonpo 2011b, pp. $193 \mathrm{ff}$.

168. Zin thig yang thig $502 / 11$.

169. rGyud bzhi 624/13, 'Bum khu tshur 289/8, Zin thig yang thig 502/11, Nyi ma'i snying po 916/12.

170. The sema plant belongs to various genera, mainly Astragalus, Oxytropis, and Hedysarum. The kyiwa plant belongs to the genus, Sophora. It is often identified as Sophora moorcroftiana (Benth.) Baker. For references, see appendix.

171. It seems that some authors identify this with Isodon rubescens, but most states that it is Artemisia species. For references, see appendix. 
172. The only exception is a recent article by Sabernig. She provides quantitative data on the use of four animal products, namely musk, elephant's bezoar, bile of a bear and rhino horn, in the Tibetan drug lists of some modern authors, see Sabernig 2011.

173. A good example is the identification of the horse in Tibetan medicine. Some modern Tibetan authors regard the horse as Equus caballus orientalis Maack, following certain publications on Tibetan materia medica written by Chinese scholars, see for instance Luo 1997, p. 331. Maack is, however, the mistaken name for Noack, which can also be found in its correct form in a Chinese publication, Zhongguo kexue yuan xibei gaoyuan shengwu yanjiusuo 1991, p.500. This identification, regardless of the correct or incorrect name's spelling, does not match any current taxonomic orders and is more or less exclusive to TCM; see, for instance, Yang 2003, p. 290,

Liu et al. 2012, p. 212. This identification seems to be based on the idea expressed by the German zoologist, Theophil Noack (1840-1918), that the horse (Equus caballus) has three types: namely E. orientalis, E. robustus, and E. przewalskii. He states "Im Besonderen muß Equus caballus in die 3 Arten: Equus orientalis, das warmblütige, Equus robustus, das kaltblütige Pferd und Equus

Przewalskii, den Pony aufgelöst werden" (Noack 1903, p. 373). It is currently unknown how exactly this notion found its way to describe a horse in TCM materia medica as an Equus caballus orientalis Noack. Today the wild horse (Equus ferus) is subdivided into the domestic horse (Equus ferus caballus), the Eurasian wild horse (Equus ferus ferus), and the Przewalski's horse (Equus ferus przewalskii). In Tibetan medicine, the domestic horse and its by-products are used for medicinal purposes, which should be properly identified in scholarly publications. In other words, one has to be cautious about the Western identification of Tibetan materia medica in modern publications. 174. See Eidmann 1941, Dlussky 1965, Bharti 2008, Thapa 2000, pp. 70ff., Pfeiffer et al. 2006, Bayartogtokh et al. 2014.

175. Narsu \& Stuart 1988, p. 8, Ding et al. 1997, pp. 215f., He \& Li 2003, Costa-Neto 2005, pp. 102f., Guo \& Zhang 2011.

176. For example, Namba states that cicada nymph skin can be used for infantile convulsions, Namba et al. 1988, p. 253.

177. Zhang \& Guo 2011, Zhang \& Liu 2014.

178. da ni rgya nag tong kun rgyal bo'i gdams pa, Bye ba ring bsrel 374/6. On the term tong kun, see Van Schaik \&Galambos 2012, pp. 170ff., Van Schaik 2013.

179. See, for instance, Namba et al. 1988, pp. 275, 277f., Ding et al. 1997, p. 213, Li et al. 2010, Mo \& Wang 2013.

\section{ABSTRACTS}

The practice of using animals and their by-products has a long history in the Tibetan medical tradition. Such therapies also often include products deriving from insects, some of which will be discussed in the present paper. After a brief introduction addressing the importance of medicinal products deriving from animals and insects in the Chinese and Indian medical traditions, the systems used by Tibetan and Mongolian doctors to classify animals will be discussed. The medicinal use of eleven insects will be examined by textual analysis, with a particular focus on the traditional description of the animal and their healing potentials. This set of eleven insects includes flies, ants, two unidentified insects, butterflies, cicadas, and four kinds of beetles, such as diving beetles and blister beetles. 
L'utilisation d'animaux et de leurs sous-produits a une longue histoire dans la tradition médicale tibétaine. De telles thérapies incluent aussi souvent des produits issus d'insectes dont certains seront présentés dans cet article. Après une brève introduction sur l'importance des médicaments issus des animaux et des insectes dans les traditions médicales chinoise et indienne, les systèmes utilisés par les médecins tibétains et mongols pour classifier les animaux seront discutés. L'utilisation médicinale de onze insectes sera examinée au travers de l'analyse textuelle, avec un accent particulier mis sur la description traditionnelle de l'animal et de son potentiel thérapeutique. Cet ensemble de onze insectes comprend des mouches, des fourmis, deux insectes non identifiés, des papillons, des cigales et quatre types de coléoptères, tels que les dytiques et les cantharides.

\section{INDEX}

Mots-clés: médecine, animaux, insecte, Tibet

Keywords: medicine, animals, insect, Tibet

\section{AUTHOR}

\section{OLAF CZAJA}

Olaf Czaja is a historian of Tibetan medicine, and his main research interests are Tibetan history, art, and medicine. He has studied the history of art, as well as Indian, Tibetan, and Mongolian studies at Leipzig, Bonn, and Kathmandu. In 2007, he obtained his doctoral degree at Leipzig University. He has written several papers dealing with various aspects of the Tibetan medical tradition. At present, he is preparing a monograph on Tibetan pharmacology.

oczaja@yahoo.de 